\title{
The New Guinea Highlands evidentiality area
}

\author{
LILA SAN ROQUE and ROBYN LOUGHNANE
}

\begin{abstract}
The article presents the first survey of grammaticized evidentiality in a cluster of languages spoken in Papua New Guinea, including the Ok-Oksapmin, Duna-Bogaia, Engan, East and West Kutubuan, and Bosavi families. We compare certain features of these languages and outline how they contribute to the typological understanding of evidentiality. Findings concern the underexplored category of participatory evidentiality, the morphological form of direct versus indirect evidentials, relationships between person, information source, and time, and complex treatments of the "perceiver" role implied by evidentials. The systems of the area are rich and varied, providing great scope for further descriptive and typological work.
\end{abstract}

Keywords: evidentiality, inflection, linguistic area, New Guinea, Papuan languages, person, syntax, tense

\section{Introduction}

Grammaticized evidentiality is recognized as an areal feature in the western United States, the western Amazon region, the Caucasus, and the Himalayas (de Haan 2008). Highlands Papua New Guinea is a further region where grammaticized evidentiality has been identified as a significant areal characteristic (Foley 1986: 165, Gossner 1994: 83). As languages with independently innovated evidentiality systems, the New Guinea group is an important missing piece in the typology of evidentiality (Aikhenvald 2004: 382-383, Plungian 2011: 22), but to date limited data and description have been available on the nature and extent of grammatical evidential markers in this region.

In this article, we present the first comparative survey of these languages, drawing together both published and previously unpublished data, and confirming the presence of a sizeable evidential Sprachbund. We report that gram- 
maticized evidentiality is present in at least fourteen languages from six language families within the larger Trans New Guinea grouping (as per the classification of Ross 2005: 22). Several of these languages have complex systems, with verbal affixes encoding up to five distinct evidential categories, plus additional knowledge-related clitics and particles. Under close analysis of the available material, a number of tendencies of potential typological significance emerge, including (i) the presence of the underexplored category of participatory evidentiality; (ii) an increased likelihood for direct evidential markers to be obligatory verbal inflections, and for indirect evidential markers to be clitics or particles; (iii) the capacity to express "double tense" with evidentials; (iv) interactions between person and evidentiality that differ according to sentence type; and (v) insights into variation in the identity of the "perceiver" role, that is, the person who is assumed to be the "eyes and ears", in evidential systems and usage.

In Section 2 we outline certain major features of evidentiality as discussed in the literature. Section 3 introduces the geographical area of study and presents data ${ }^{1}$ from each language family, moving roughly from west to east, then curling south and back to the west. In Section 4 we compare and discuss particular features of the languages' evidentiality systems, and in Section 5 we reiterate the importance of the area to developing a comprehensive understanding of grammaticized evidentiality in crosslinguistic perspective.

\section{Background: Evidentiality}

\subsection{Evidential terms used}

Evidentiality is generally understood to relate to the evidence a speaker or other perceiver (henceforth simply "speaker") has for their utterance. For example, in the language Oksapmin, the reported evidential clitic $=l i$ 'REP' indicates that the speaker's evidence for the utterance is hearsay (1). In this example, and in Oksapmin and Duna examples that follow, an approximation of the meaning communicated by the evidential marker is shown in curly brackets in the translation line (cf. San Roque 2006, Tatevosov 2007).

1. Previously published material for Oksapmin, Huli, Enga, Pole, Kewa, Foe, Fasu, and Kaluli and previously unpublished material for Oksapmin (Loughane 2009 and fieldnotes), Duna (Giles no date, San Roque 2008 and fieldnotes), Bogaia (Seeland 2007a, b), Huli (Lomas 1988 and personal communication; Rule 1974), Ipili (Terence Borchard, e-mail communication; Frances Ingemann, e-mail communication), certain Angal varieties (Madden no date; Hans Reithofer, personal communication), Kaluli (Rule no date), Edolo (Gossner 1994), Onabasulu (Anne Dondorp, personal communication), and Wiru (Kerr 1967). 


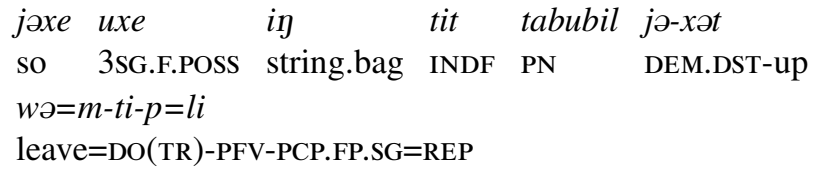

There is some disagreement in the literature over what can and cannot be called an evidential. Two major stances discussed by Chafe (1986) can be characterized as "broad" versus "narrow" senses of evidentiality (Willett 1988, Mushin 2001).

Formally, in the narrow sense, evidentiality does not extend to adverbs, auxiliary verbs, or idiomatic phrases but "is a grammatical system (and often one morphological paradigm)" (Aikhenvald 2004: 6). Ideas on whether evidentials must comprise an obligatorily marked category differ (see Brugman \& Macaulay 2010 for a recent survey). In the "broad" view, adverbs, auxiliary verbs, and idiomatic phrases may be counted as evidential (Chafe 1986: 261). Boye \& Harder (2009) argue for an even more inclusive definition of evidentiality as a "substance domain" that potentially incorporates lexical items (e.g., perception verbs).

Semantically, in the narrow definition, evidential terms index the source of information for an event as their primary meaning (Anderson 1986). Proponents of the narrow definition of evidentiality view epistemic meanings of evidentials as extensions that do not represent the core semantics of the evidential: pragmatic inferences that are not the norm (see, e.g., Aikhenvald 2004: 7-8). For example, a reported evidential as in (1) MIGHT convey that the speaker is not sure about the described situation, but this follows from the information source meaning, and is not a necessary condition for the morpheme's use. Proponents of the broad definition of evidentiality argue that evidentiality necessarily says something about reliability (or other evaluative properties) of knowledge (Chafe 1986) and the truth value of a proposition (Palmer 2001). For example, reported evidentiality is viewed as an expression of reduced commitment to an utterance. In the broad definition, factors such as the interactional setting and pragmatics are considered by the speaker in combination with the actual evidence when selecting an evidential marker. Thus, evidential marking expresses an epistemological stance, not a literal source of information (see Mushin 2001).

In Section 3 we discuss narrow evidentials in the languages under study and, where possible, describe certain broad evidentials that are likely to be relevant to the narrower evidential systems. We do not take obligatoriness as a requirement for narrow grammatical status, although we do recognize it as significant 
Table 1. Willett's evidential categories (adapted from Willett 1988: 57)

\begin{tabular}{|c|c|c|c|c|c|}
\hline \multirow{8}{*}{$\begin{array}{l}\text { Types of } \\
\text { Evidence }\end{array}$} & \multirow{3}{*}{\multicolumn{2}{|c|}{ Direct }} & \multirow{3}{*}{ Attested } & \multicolumn{2}{|l|}{ Visual } \\
\hline & & & & \multicolumn{2}{|l|}{ Auditory } \\
\hline & & & & \multicolumn{2}{|c|}{ Other Sensory } \\
\hline & \multirow{5}{*}{ Indirect } & & \multirow{3}{*}{ Reported } & \multirow{2}{*}{ Hearsay } & Second-hand \\
\hline & & & & & Third-hand \\
\hline & & & & \multicolumn{2}{|l|}{ Folklore } \\
\hline & & & \multirow{2}{*}{ Inferring } & \multicolumn{2}{|l|}{ Results } \\
\hline & & & & \multicolumn{2}{|c|}{ Reasoning } \\
\hline
\end{tabular}

in distinguishing types of evidentials in the region of study (see Section 3.2). In Section 4 we largely restrict our comparison and discussion to narrow evidentials due to data restrictions and in order to maximize comparability.

Previous researchers have identified a number of semantic parameters that recur in narrow evidential categories of the world's languages. In his early crosslinguistic survey of 38 languages with grammaticized evidentiality, Willett (1988) distinguishes the evidential categories shown in Table 1. These are similar to those identified by Aikhenvald (2004), except that Willett distinguishes auditory from non-auditory sensory evidentials, and Aikhenvald treats these as a single category; and Willett divides reported evidentials into three categories, whereas Aikhenvald discusses only two (conflating second- and third-hand reports).

In our analyses, we distinguish as many evidential categories as are necessary to represent the maximum number of grammaticized distinctions that are well attested in the languages under discussion. These are as follows:

(i) Participatory (glossed as PCP): the speaker performed the event

(ii) Visual (VIS): the event was seen

(iii) Sensory (SENS): event was perceived with non-visual senses

(iv) Reported (REP): the speaker was told of the event

(v) Results (RESU; cf. Aikhenvald's "inferred" category): the speaker observed evidence that is a result of the event in question

(vi) Reasoning (REAS; cf. Aikhenvald's "assumed"): inference based on complex and creative deduction, commonly involving a synthesis of several different knowledge sources.

Note that the use of "sensory" here includes both Willett's "auditory" and "other sensory" categories (smell, taste, touch, and commonly also internal feeling); see individual language sections in Section 3 concerning potential auditory-only categories. Likewise, a single "reported" category is discussed here, conflating Willett's "second-hand", "third-hand", and "folklore".

In addition to the categories outlined by Willett and Aikhenvald, we distinguish participatory evidence, following Rule (1977). Participatory evidential- 
ity, or similar categories, have been referred to in the literature as the "participatory" for Foe (Rule 1977), "performative" for Kashaya (Oswalt 1986), "personal agency" for Central Pomo (Mithun 1999), and the "participatory" (also “personal") for Oksapmin (Loughnane 2007, 2009). Oswalt (1986: 34) defines this category for Kashaya as indicating that "the speaker knows of what he speaks because he is performing the action himself or has just performed it", as illustrated in (2).

$$
\begin{aligned}
& m i \cdot-l i \quad \text { Pa me-Pe-l } \quad p^{h} \text { akúm-mela } \\
& \text { there-VISIBLE I your-father-o kill-PCP } \\
& \text { 'Right there I killed your father.' (Oswalt 1986: 35) }
\end{aligned}
$$

Participatory evidentiality can be thought of as belonging to a broader field of "ego evidentiality", defined by Garrett (2001: 105) as being to do with "immediate knowledge, [...] mediated by neither perception nor inference". Ego evidentiality contrasts with visual evidence, which, while direct, is not as direct as embodied experience, the "evidence" that springs from being oneself. ${ }^{2}$

As discussed in Section 3.3, a single evidential category in a given language can incorporate both participatory and factual evidential semantics. Factual evidentiality relates to "actions or states which have been observed enough by the speaker for him to generalize them as true, and [...] and which are simply common knowledge" (Oswalt 1986: 36). It appears to be quite rare for factual semantics to be encoded as a distinct category within an evidential system, ${ }^{3}$ and such meanings are probably more typically found as a component (extensional or otherwise) of participatory and/or visual evidential categories (see also Oswalt 1986, Mithun 1999, de Haan 2001, McLendon 2003). Plungian

2. For the languages we discuss (Oksapmin, Foe, and Fasu), ego evidentiality involves active participation in the described event, as in Oswalt's (1986) definition for Kashaya. Other kinds of ego evidentiality that are distinguished in the world's languages may specify the experience of being an undergoer rather than an actor (e.g., "conjunct undergoer" in Awa Pit, Curnow 2002a; "personal affectedness" in Central Pomo, Mithun 1999), or be restricted to the private experience of internal sensations or emotions (e.g., the Korean experiential construction as described by Chun \& Zubin 1990, Mushin 2001). Plungian (2011: 33-34) characterizes the latter as "endophoric" evidentiality (citing Tournadre 1996 and Claude Hagège), and points out similarities between participatory and endophoric semantics. It is not clear how he regards undergoer experience more generally.

3. Note that Mushin (2001) appears to view "factual" as standing apart from information source, as she describes factual epistemological stance as: "reflected in the ABSENCE of any representation of the source of information (and its status) in the construal. Adoption of a factual epistemological stance typically implies either that the information is assumed to be known by anyone in the speech community as general cultural knowledge or, more generally, that the source of information is unimportant to the establishment of the validity of the information" (Mushin 2001: 74). 
(2011: 36-37) argues that participatory and factual are important values deserving special discussion as crosslinguistic classifications of evidentiality are expanded and improved.

For ease of reading, we have altered glosses for evidential terms from other sources to those glosses described in association with Table 1. (Terms from the original sources are shown in Tables 4 to 14 in Section 3.) The six category divisions we employ (participatory, visual, sensory, results, reasoning, reported) are comparable across the languages of our focus area, but, as the above comments suggest, the semantics encoded by the evidential morphemes in question may not be identical for each category. For example, the reported morpheme in Oksapmin is used for second-hand, third-hand, and folklore, whereas in Duna and Fasu the reported morpheme is used for third-hand and folklore only; second-hand reports are coded by other means. The categories may not be exhaustive (see, e.g., possible additional distinctions suggested for Huli in Section 3.5.2), and it is a possibility that other morphemes and categorical arrangements relating to evidentiality will emerge from further study of these languages.

\subsection{Evidential hierarchies}

A number of researchers have proposed hierarchies of evidential categories. Aikhenvald (2004: 307) proposes the hierarchy given in (3) for Tuyuca and Tariana; see also Barnes (1984).

$$
\text { Visual }>\text { Non-Visual }>\text { Inferred }>\text { Reported }>\text { Assumed }
$$

In this hierarchy, visual evidence is the "strongest" evidence available to a speaker of these languages. A speaker usually chooses the strongest form of evidence they have available for an event as determined by the hierarchy. For example, if a person both saw an event and was told about the event, they would choose the visual, rather than the reported, evidential.

Oswalt (1986: 43) proposes the hierarchy given in (4) for Kashaya (Pomoan family), which includes the category "performative" ("participatory" in our terms).

Performative $>$ Factual-Visual $>$ Auditory $>$ Inferential $>$ Quotative

According to Oswalt, a speaker "would not normally attribute knowledge of [an] event to a lower type of evidence, unless of course, he is speaking in a detached way as an observer of his own actions" (Oswalt 1986: 43).

These hierarchies reflect the common conversational implicature of certain evidentials regarding reliability of knowledge (see Chafe 1986). Prototypically, the more "direct" evidence is, the more reliable the knowledge and the higher it ranks on the hierarchy (see also Faller 2002). The hierarchy then embodies 
the Gricean maxim of quality: try to make your contribution one that is true (Grice 1975: 27). That is, a speaker should present the most reliable knowledge they have for an event. Where evidence justifying the use of a more reliable evidential is available, the use of an evidential that is lower on the hierarchy is pragmatically marked (see Oksapmin example 8c) or otherwise infelicitous. ${ }^{4}$

As with any other part of language, different languages cut up the evidential semantic space in different ways, grouping compatible concepts together in single markers. For example, if a given language has only two evidentials, these might encode direct versus indirect (as in Table 1); if it has four, then perhaps visual, sensory, inferring, and reported. Grouped meanings are typically contiguous on the prototypical hierarchy; for example, in Oksapmin visual and sensory are conflated as a single category (VIS/SENS), whereas in Angal Henen/Heneng one inflection expresses sensory, results, or reported evidence (SENS/RESU/REP).

\subsection{The "perception event" in evidential systems}

A concept important to discussing evidential systems is the distinction between what we refer to as the "main predicate event" - the situation that is described by the clause - and the "perception event", that is, the experience of seeing or sensing (etc.) that is evoked by the evidential morpheme (see also Jakobson 1957, Kockelman 2004, Speas 2004). In (5) from Oksapmin, there are two distinct events expressed: the woman coming (the main predicate event); and the speaker seeing the woman coming (the perception event).

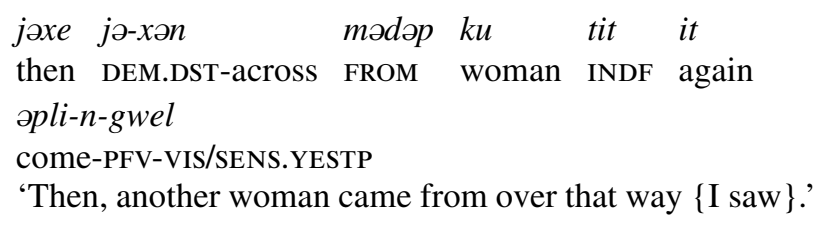

The perception event encoded by an evidential marker can be thought of as having its own participant(s) and time reference, including an "evidential origo" (Brugman \& Macaulay 2010), the person who experiences the evidence in question (see also discussion of the roles of "experiencer" in Mushin 2001; "epistemic source" in Hargreaves 2005; "informant" in Bickel \& Nichols 2007). In (5) the evidential origo is the speaker; she or he is understood to be the one who saw the event in question. This is an example of the subjectivity of

4. The same pattern is observable in English periphrastic constructions. For example, Mushin (2001: 72) notes that the sentence ?? I heard that I'm exhausted is awkward because it presents an event for which evidence is usually acquired through personal experience (higher on the evidence hierarchy) as if it were known about through hearsay (lower on the hierarchy). 
language, the "expression of self and the representation of a speaker's (or, more generally, a locutionary agent's) point of view in discourse" (Finegan 1995: 1).

It is common for the perceiver to be understood to be the speaker, and there is an assumption in much of the literature that this is an essential part of evidentiality (see Brugman \& Macaulay 2010 for discussion). However, this does not have to be the case. As Mushin (2001: 12-13) writes:

Subjectivity in language is not simply about representing the speaker's imprint. Rather it is about the representation of some designated experiencer's imprint which may or may not coincide with the identity of the speaker.

With reported evidentiality, for example, many languages can "stack" evidentials, allowing the expression of multiple perception events and, therefore, multiple perceivers. This is shown in (6), again from Oksapmin, where there are two perception events expressed in addition to the main predicate event (the chick being there): the original speaker (the mother) witnessing the event, as expressed by the visual-sensory evidential inflection -gop; and the current speaker having been told about the event, as expressed by the reported evidential $=l i$.

(6)

$$
\begin{aligned}
& \text { sup ux ay t-x-t us jox=o } \\
& \text { mother.3.POss 3sG.F find MID-make-SIM go.PRS.SG TOP=EMPH } \\
& \text { sjap bap tit }=o \quad p t-n-g o p=l i=o \\
& \text { cassowary small INDF=EMPH stay-PFV-VIS/SENS.FP.SG=REP=EMPH }
\end{aligned}
$$

'When the mother went searching around, there was a cassowary chick \{ she saw, I was told\}.'

Beyond reported evidentiality, for certain of the languages under discussion here evidential markers can also cast the addressee as perceiver, or be used to reflect the evidential viewpoint of the central figure in a narrative, or even reference generalized potential perceptual experience for which no particular perceiver is specified. There is also scope for evidential constructions to encode a distinct time reference for the perception event, relative to the speech event (cf. Fleck 2007). For the evidential markers where this is relevant we specify whether the evidence is "current" with the speech event (i.e., is observed at the time of speaking) or is "previous" to it (i.e., observed before the time of speaking). These phenomena are discussed further in the relevant language sections and in Section 4. 


\section{Language survey}

\subsection{Introduction to the area}

The area of Papua New Guinea under study stretches from Sandaun Province in the west through Southern Highlands Province ${ }^{5}$ and into Enga Province. The presence of grammaticized evidentiality as an areal feature in this region was identified by Foley (1986: 165). Languages that are known to have evidentiality marking are Oksapmin, Duna, Bogaia, Huli, Enga, Ipili, Pole, Kewa, the Angal group, Foe, Fasu, Onabasulu, Kaluli, and Edolo, as shown in Map 1.

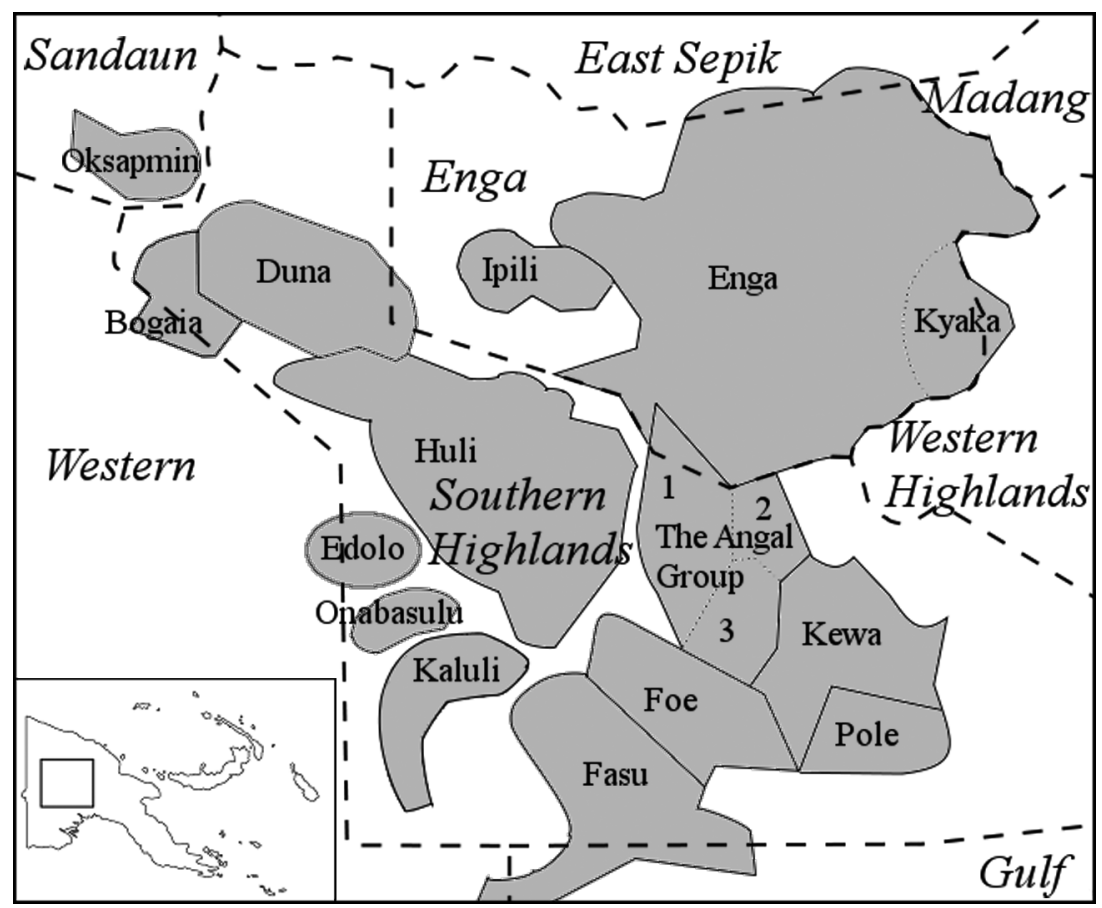

Map 1. Languages of the Papua New Guinea Highlands evidentiality area (shaded grey). Based on SIL maps (Gordon \& Grimes (eds.) 2005) and Haley (2002). A dotted line indicates that a language boundary is uncertain. Province names are shown in italics and province borders with dashed lines. The Angal group varieties are Angal Heneng (1), Angal Henen (2), and Angal Enen (3).

5. Southern Highlands is expected to be separated into two distinct provinces, Hela and Jiwaka, in 2012. 
The languages discussed in this article are classified as belonging to six different families within the larger Trans New Guinea grouping (Ross 2005: 22): Ok-Oksapmin (Section 3.3), Duna-Bogaia (Section 3.4), Engan (Section 3.5), West Kutubu (Section 3.6), East Kutubu (Section 3.7), and Bosavi (Section 3.8). The languages share certain typical Trans New Guinea structural features, such as unmarked SOV constituent order and a distinction between medial (minimally inflected and dependent) and final (fully inflected and independent) clauses. Core argument NPs can generally be omitted when recoverable from context. With the exception of the Engan family languages, they are less typical examples of Trans New Guinea in that subject person is rarely an obligatory verbal inflection (see also Section 4).

Melpa varieties spoken to the east of the Angal languages and the isolate Wiru spoken to the east of Kewa have constructions that are relevant to information source marking, and these are briefly discussed in Section 3.9.

Only limited data are available for several additional languages that could potentially share the areal feature of grammaticized evidentiality. There are indications that Samo (K. Shaw 1973: 210,212) and Aekyom (Stewart 1989: 45) to the west of the known area, and Hewa (Cochran 1968: 138), spoken to the north of Duna, have one or more dependent or independent verbal affixes that refer to information source, and these are important areas for further investigation. Descriptions of the Ok languages to the (north-)west of the known area (P. Healey 1965; Fedden 2007, 2011) indicate that grammaticized evidentiality is not present.

Several other languages throughout New Guinea have been identified as having evidential markers or conventionalized evidential strategies (see, e.g., Bugenhagen 1995, MacDonald 1990, Quigley forthcoming, de Vries 1990). These languages are not contiguous with the Highlands evidentiality area and are not included in this survey.

\subsection{Method and scope of the survey}

In Sections 3.3 to 3.8, we describe the grammaticized narrow evidential distinctions in each language and how these are coded. Where possible, the language sections include information on other morphemes that are especially relevant to broad evidentiality.

In order to examine how categories are formally contrasted in the languages under study, we make a broad distinction between inflectional and noninflectional morphology. This aids in understanding not only how information source is distinguished, but also how the relevant markers work within the morphological system of each language. The criteria we have used for determining whether something is verbal inflection are the following: (i) the markers occur in a fixed paradigm which is applied to verbs and not other word classes, and 
(ii) the paradigm can be understood as represesenting an obligatory category (or categories) on final verbs. In the language examples, we use a hyphen to show ligature with what we determine to be inflectional markers, and an equals sign to show ligature with what we determine to be non-inflectional markers. For languages where little data are currently available our assessment of the inflectional status of these markers should be treated as a hypothesis requiring further testing.

As with other types of verbal inflection, it is sometimes difficult to ascertain which evidential categories are distinguished in a given language. The inherent slipperiness of semantically grounded categories is further complicated by the fact that many of the materials available are sketches that do not focus on evidential semantics, and/or predate key comparative works on evidentiality. Overall, the most accurate analysis possible was made by examining both the researchers' definitions and the use of the morpheme in question in texts and example sentences. Where there is unresolvable conflict between these two types of material, or not enough information obtainable from either, we do not include the marker(s) in question in our final comparison (Section 4). For reasons of space we do not provide examples illustrating all of the posited evidential markers for each language, but focus on those that are necessary for explanatory purposes and/or are drawn from less accessible works.

In certain cases, inflectional visual or sensory evidential markers are in paradigmatic opposition to other overt verbal inflections or to a potential zero morpheme (Huli, Enga, Ipili, Edolo). The available descriptions do not unequivocally indicate that these opposing inflections have particular information source semantics, and we have not analyzed them as evidential inflections. However, it remains plausible that they encode participatory, factual, and/or visual meaning, and that evidentiality can thus be understood as a strictly obligatory inflectional category for these languages. Further examination of the relevant verb forms, preferably in corpora of spontaneous speech, will help to establish the validity of such an analysis for each of the languages.

Several of the evidential markers we discuss show apparent formal relationships to each other, both within and across families, suggesting possibilities for examining the origins and relationships of the evidential forms, and of the mechanisms that shape the development of this Sprachbund. We do not explore these complex issues here, but leave them as topics for further research.

\subsection{Oksapmin}

Oksapmin (Ok-Oksapmin family) is spoken by approximately 8000 people living in the southeast corner of Sandaun Province. (See Lawrence 1993, 2006, and Loughnane 2009 for further location and dialect information.) Previously thought to be an isolate (A. Healey 1964, Lawrence 1993), it has recently been 
Table 2. Oksapmin evidential forms

\begin{tabular}{|c|c|c|c|}
\hline Evidential category & Form & $\begin{array}{l}\text { Verbal } \\
\text { inflection? }\end{array}$ & Description \\
\hline Participatory & (verb paradigm) & yes & $\begin{array}{l}\text { speaker consciously } \\
\text { performed the event; generally } \\
\text { known facts }\end{array}$ \\
\hline Visual, sensory & (verb paradigm) & yes & $\begin{array}{l}\text { speaker witnessed or } \\
\text { otherwise sensed the event }\end{array}$ \\
\hline Reported & $=l i$ & no & known via hearsay \\
\hline Results, reasoning & $s a \sim s e$ & no & $\begin{array}{l}\text { inferred from evidence or } \\
\text { mental processes }\end{array}$ \\
\hline
\end{tabular}

grouped with the Ok family (Loughnane \& Fedden 2011). Oksapmin has the evidential markers shown in Table 2. See Loughnane (2009) for the actual verb forms.

Oksapmin contrasts participatory and visual-sensory evidentiality in past tense forms only. The evidential distinction is also discussed by Lawrence (1987) as "viewpoint". The Oksapmin participatory evidential category incorporates factual information source semantics and is referred to by Loughnane (2009) as "personal-factual".

The participatory past tenses are primarily used in the following situations:

(i) 1 st person statements about events which the speaker consciously performed (7a);

(ii) 2nd person questions about events which the speaker anticipates that the addressee consciously performed (7b);

(iii) uncontested facts (3rd person) for which the speaker has accumulated various types of evidence which is also available to the addressee $(7 \mathrm{c})$.
a. nuxut gal $m$
di-pa
$1 \mathrm{DU}$ cut DO(TR)(.SEQ) eat.PFV-PCP.FP.PL
'We cut it up and ate it $\{\mathrm{I}$ did it $\}$.'
b. go koli ox=nuy wa de-l=d=o
2SG PN 3sG.M=O see DO(TR)-IPFV.PCP.TODP=PQ=EMPH
'Did you see Koli $\{$ you did it\}?'
c. joxe awxen-il ixile dik jox kukumi jox so grandparent-PL 3PL.POSs time DEF brideprice DEF
[...] $i=m a$
jox $=$ si
moxe-sxe
DEM.DST $=$ REL DEF=WITH buy-PCP.FP.PL.HAB

'So, in the elders' time, they used to pay the bride price [with pig's teeth, bows, arrows, axes and stone axes,] with these things $\{$ it is a fact $\}$.' 
The visual-sensory past tenses are primarily used in the following situations:

(i) 2nd or 3rd person statements or questions about events the speaker witnessed (8a), heard, or otherwise sensed (8b); and

(ii) 1 st person statements or questions about events for which the speaker does not have participatory evidence or is putting the onus of evidence onto the hearer for pragmatic reasons $(8 \mathrm{c})$.
a. tom xulu jox oksapmin mə-xəm
water pond DEF PN DEM.PRX-down
pt-nipat
be-VIS/SENS.FP.SG.HAB
'There was a pool down at Oksapmin station $\{$ I saw $\}$.'
b. nox tom din wanxe n-x-n-gwel
1sG water thirsty a.lot 1/2.O-DO-PFV-VIS/SENS.YESTP
'I was really thirsty $\{$ I felt $\}$.'
c. apun mə=te n-p-n-gwel
yesterday DEM.PRX=place 1/2.O-Say(TR)-PFV-VIS/SENS.YESTP
$\max =a$
RECG $=$ EMPH
'Yesterday, in this place, I told you that \{you heard\}.' [Context: speaker ordered someone to leave but they did not leave and re- turned to him the next day against his orders.]

Separate light-verb and serial-verb constructions are also used for visual, sensory, and auditory evidence, but these do not fall under the scope of this article (for details, see Loughnane 2009: 428-430, 458-463).

In addition to the inflectional evidential distinction in the past tense, Oksapmin has a number of clitics and particles which indicate the epistemological stance of the speaker. Of these, $=l i$ 'reported' and $s e \sim s a$ 'results-reasoning' may be classed as evidential in the narrow sense.

The high-frequency reported clitic $=l i$ indicates that the speaker obtained the information via hearsay and did not directly witness the events in question. The information may be second-hand, third-hand, or folklore, as in (9).

$$
\begin{aligned}
& \text { xan nəgmd-il mox pt-sxe=li } \\
& \text { man sSSIBS-PL ANPH be-PCP.FP.PL.HAB=REP } \\
& \text { 'There were once (five) brothers }\{\text { they did it, I was told }\} . \text { ' }
\end{aligned}
$$

In narrative, the clitic $=l i$ occurs with the participatory inflection when the subject is the main or currently important character in the story. That is, the verbal inflection is the same as a speaker would use to directly relate 1st person events they consciously performed.

In a 3rd person narrative, events which are seen, heard, or felt by the main character take the visual-sensory past tense forms with the reported marker, as 
shown in (10). These are events witnessed by the (real or imaginary) original speaker and are told exactly as the original or imagined speaker would have relayed the events but with the reported clitic on the end of each sentence.

$$
\begin{aligned}
& \text { ap tit tux ml-pat-gop=li } \\
& \text { house INDF smoke come.up-IPFV.SG-VIS/SENS.FP.SG=REP } \\
& \text { 'There was smoke coming up from a house }\{\text { he saw, I was told \}.' }
\end{aligned}
$$

The preverbal particle $s e \sim s a$ indicates that information is based on an inference by the speaker due to visible or otherwise sensed results. This particle obligatorily co-occurs in a construction with the participatory forms 6 (in past tenses) in a complement clause of speech or with the reported clitic, as shown in (11).

$$
\text { se } \quad \text { su-m } m \text {-di-p=li tupun jox }
$$

RESU/REAS kill-SEQ ANPH.O-eat.PFV-PCP.FP.SG=REP thumb DEF

'She killed and ate him, the first one \{he inferred, I was told \}.' [Context: the reported speaker infers that the eldest brother was killed and eaten by the girl because he found the brother's jaw bone in her house.]

\subsection{Duna-Bogaia family}

3.4.1. Duna-Bogaia overview. The territories of the Duna (Section 3.4.2) and Bogaia (Section 3.4.3) language groups are in the northwest of Southern Highlands Province. Based on a limited amount of pronominal and lexical correspondences, the two languages are classified together as a single family (Ross 2005, R. Shaw 1973, Voorhoeve 1975). Duna speakers are estimated to number more than 20,000 (Haley 2002), but there are only a few hundred speakers of Bogaia, most of whom are under pressure to shift to Duna and/or Tok Pisin as languages of daily communication (San Roque 2008).

Bogaia and Duna do not show person or number agreement on the verb for subject or object (with the exception of a few suppletive forms). Both languages distinguish at least visual and sensory categories in their basic evidential morphology, and have additional morphemes or structures for indicating results evidence. Duna also distinguishes reasoning and reported evidence. The evidential markers of these languages are non-inflectional according to the criteria outlined in Section 3.2.

6. When the participatory inflections occur with another evidential or epistemic particle or clitic (excepting the reported clitic), they act as the functionally unmarked past tense forms and are semantically bleached of evidential meaning. The participatory versus visual-sensory distinction is kept when the reported clitic is used. The visual-sensory forms may also be used in a 3rd person imperative construction with a preverbal particle which contrasts formally with se $\sim s a$, in which the visual-sensory semantics are bleached; see Loughnane (2009) for details. 
3.4.2. Duna. This account of Duna evidential morphemes is largely limited to their occurrence on final verbs in declarative sentences. Further description of Duna can be found in Cochrane \& Cochrane (1966), Giles (no date), Rule (1966), and San Roque (2008).

Duna evidential morphemes distinguish five kinds of information source, as indicated in Table 3. Most categories further specify the time of perception as being current with or previous to the time of speaking. The forms shown in Table 3 are mutually exclusive and can occur on bare verb roots, functionally contrasting with TAM inflections (see also Section 4.2). However, several can also occur on non-verbal predicates, in referential NPs, and in combination with TAM inflections. For the purposes of this survey we treat the Duna evidentials as non-inflectional.

Examples (12) and (13) show five Duna descriptions of the same past event, the baking of a pig. The verb in (12a) is inflected with the perfective suffix $o$, which does not specify information source (see San Roque 2008: 336-339).

Table 3. Duna narrow evidentiality morphemes (individual evidence, regular forms)

\begin{tabular}{|c|c|c|c|c|}
\hline $\begin{array}{l}\text { Evidential } \\
\text { category }\end{array}$ & & Form & $\begin{array}{l}\text { Verbal } \\
\text { inflection? }\end{array}$ & Description \\
\hline \multirow[t]{2}{*}{ Visual } & $\begin{array}{l}\text { stative pre- } \\
\text { vious }\end{array}$ & $=$ rua & no & stative event was seen \\
\hline & $\begin{array}{l}\text { perfective } \\
\text { previous }\end{array}$ & $=t i a$ & no & non-stative event was seen \\
\hline \multirow[t]{2}{*}{ Sensory } & current & $=$ yarua & no & $\begin{array}{l}\text { event is currently sensed } \\
\text { (heard, smelt, tasted, felt) }\end{array}$ \\
\hline & previous & $\begin{array}{l}=y a r i t i a \\
=y a t i a\end{array}$ & no & event was previously sensed \\
\hline \multirow[t]{2}{*}{ Results } & current & $=r e i$ & no & $\begin{array}{l}\text { currently inferred from } \\
\text { (visible) evidence }\end{array}$ \\
\hline & previous & $=$ rarua & no & $\begin{array}{l}\text { previously inferred from } \\
\text { (visible) evidence }\end{array}$ \\
\hline Reasoning & current & $=$ no $i$ & no & $\begin{array}{l}\text { realized (with surprise) to be } \\
\text { the case based on some } \\
\text { current evidence; a hypothesis }\end{array}$ \\
\hline Reported $^{\mathrm{a}}$ & previous & $=$ norua & no & $\begin{array}{l}\text { event known about from a } \\
\text { thirdhand report, or } \\
\text { inaccessible orginal source }\end{array}$ \\
\hline
\end{tabular}

a. The "reported" form can also be analysed as belonging to the "reasoning" category, with a specification for a previous rather than current perception; see San Roque (2008: 325-331). 
The verbs in (12b) and (12c) are marked with visual and sensory evidentials, respectively. The visual or sensory perception of the baking happened before the speech event. There is no other overt temporal reference marked on the verb, and the evidential specification also supplies a past time reading for the baking itself (see also Section 4.2).

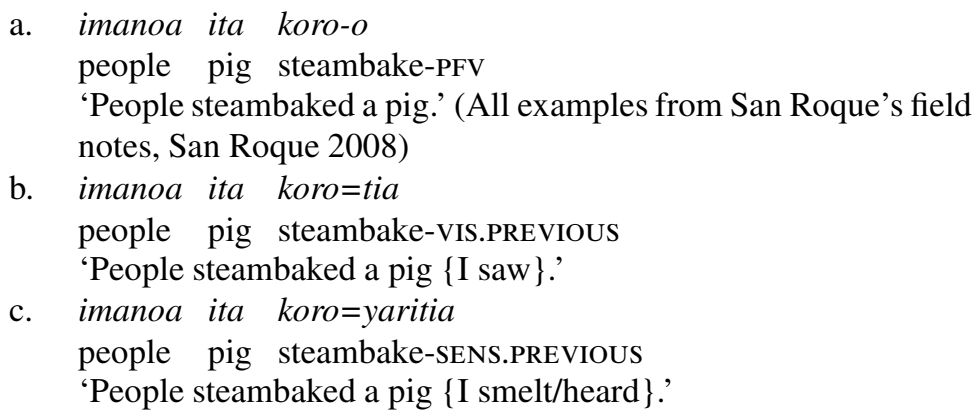

The results category morphemes =rei and =rarua indicate that a past event is inferred from evidence, particularly visible evidence; in one discussion two Duna consultants explained the meaning of the results evidential as "to see and know" (original definition in Tok Pisin: lukim na save). Example (13a), the current form, would be appropriate when viewing the evidence of the pigbaking (e.g., remains of a fire and pit). Example (13b) would be used when one has left the site and is telling someone else about the event.

a. imanoa ita koro $=r e i$

people pig steambake-RESU.CURRENT

'People steambaked a pig $\{$ I infer $\}$.'

b. imanoa ita koro=rarua

people pig steambake-RESU.PREVIOUS

'People steambaked a pig $\{$ I inferred $\}$.'

Examples (12) and (13) describe a past time event, for which the widest number of evidential contrasts is available in Duna (as is generally true crosslinguistically, see Aikhenvald 2004). In addition to the examples presented, a speaker can also use reasoning and report evidentials to present a past event as a (surprising) realization, or as a third-hand report, respectively. For present time events, the options are very different, as the only evidential marker available is the sensory (current) morpheme =yarua (see San Roque 2008 concerning other present time TAM inflections). This form is prototypically used in describing events that are heard, smelt, tasted, or felt, but can also be extended to mark inference from current evidence concerning past, present, and future events (see Section 4.2). 
In (12) and (13), the evidential markers encode the viewpoint of a particular individual, the speaker. An addressee or 3rd person can also be treated as a perceiver in the appropriate context (see Section 4.4, Gillespie \& San Roque 2011). Distinct from the morphemes presented in Table 3, a further set of four "impersonal" evidentials in Duna encode visual, sensory, results, and reasoning-reported information source, but without an expectation that the perceiver is a single individual. Rather, the evidence is described as generally perceivable, without indicating by whom. The impersonal evidentials show a clear formal relationship to the individual evidentials in Table 3 (e.g., the impersonal sensory form is =yanua, corresponding to the individual sensory current form =yarua), and are mutually exclusive with them. See San Roque (2008: 331334) for examples.

Duna evidentials do not usually occur on verbs with a 1st person subject except in restricted contexts, for example, expressions of involuntary bodily experience (e.g., feeling ill), dream descriptions, rhetorical questions, reported utterances, and certain other embedded or dependent clauses.

In addition to the set of evidential markers already discussed in this section, Duna has a number of bound morphemes that relate to broad evidentiality. The set of "information status markers" (San Roque 2008: 339-346) indicate features such as verifiability, uncertainty, and surprise, in some cases encoding the speaker's assessment regarding the addressee's awareness of, or access to, the information. Information status markers functionally contrast with TAM inflections and evidentials, but some of them can also occur WITH evidential morphemes.

Certain Duna particles and constructions are also relevant to the expression of evidential or knowledge-related meanings, for example, the final particle pi marks a proposition as an evidence-based personal opinion. Complementtaking predicates ruwa- 'say' and ke- 'see' are used in analytic evidential strategies, for example in expressing reported information, and in describing events that are habitually observed (San Roque 2008).

3.4.3. Bogaia. Seeland (2007a, b) describes two evidential morphemes in Bogaia (Table 4). These are added to inflected final verbs and distinguish visual and sensory evidence categories. The leftmost column of Table 4 shows the names used by the original author for the morphemes in question. The next column identifies the evidential category marked by the affix, following the terminology outlined in Section 2.

According to the current data, the Bogaia visual evidential $=k i$ can be added to a verb inflected for present tense (14a) or past tense (14b). In a number of examples, the visual marker plus past tense can be interpreted as indicating inference from observed evidence, suggesting a constructional semantic/pragmatic 
Table 4. Bogaia evidential verbal affixes (from Seeland 2007a)

\begin{tabular}{|c|c|c|c|c|}
\hline Seeland's term & $\begin{array}{l}\text { Evidential } \\
\text { category }\end{array}$ & Form & $\begin{array}{l}\text { Verbal } \\
\text { inflection? }\end{array}$ & Description \\
\hline $\begin{array}{l}\text { Sense perception } \\
\text { (Seeing) }\end{array}$ & Visual & $=k i$ & no & $\begin{array}{l}\text { "the speaker has witnessed } \\
\text { first hand what is being } \\
\text { commented on and therefore } \\
\text { knows it to be true based on } \\
\text { the perceived facts" (Seeland } \\
\text { 2007b) }\end{array}$ \\
\hline $\begin{array}{l}\text { Sense perception } \\
\text { (Hearing) }\end{array}$ & Sensory & $=a i$ & no & $\begin{array}{l}\text { "an action has not been seen } \\
\text { but has been heard" (Seeland } \\
\text { 2007a) }\end{array}$ \\
\hline
\end{tabular}

extension of the visual marker. ${ }^{7}$

$$
\begin{aligned}
& \text { a. ami fosi=ki } \\
& \text { [man come.PRS.ACTIVE=VIS] } \\
& \text { 'A man is coming. (I see him coming.)' (Seeland 2007a: 9) } \\
& \text { b. ho mabaro wagan mogona=ki } \\
& {[3 \mathrm{SG} \text { pig hunt go.PST=VIS] }}
\end{aligned}
$$

'He has gone to hunt pigs. (I saw him go.)', or 'I see evidence that he went.' (Seeland 2007a: 9 and Seeland, personal communication)

The sensory evidential is added to present tense (active aspect) forms only. An example is shown in (15).

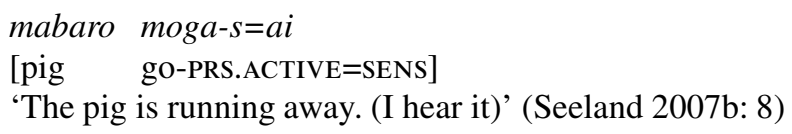

The sensory marker $=a i$ is described in relation to auditory evidence only (Seeland 2007a). However, there are very few examples of this morpheme and currently no evidence that Bogaia makes a distinction between hearing and other kinds of non-visual evidence (i.e., smell, taste, and touch). We treat the Bogaia auditory category as comparable to the sensory category of other betterknown languages of the area. Further data will establish if this approach is correct (see also Section 3.8.3).

7. Here and elsewhere, interlinear glosses shown in square brackets have been added by San Roque \& Loughnane, drawing from information supplied in the source descriptions. 
For the purposes of this survey we class the Bogaia evidentials as noninflectional. However, certain features suggest that the sensory evidential marker could be analysed as a verbal inflection that formally contrasts with an unmarked present tense. ${ }^{8}$ All examples of evidential morphemes in Seeland's description are with verbs that have 3rd person subjects, suggesting that marking 1 st and 2 nd person activities with evidentials is atypical.

\subsection{Engan family}

3.5.1. Engan overview. The Engan language family spreads through Southern Highlands and Enga provinces and has a small presence in East Sepik. Enga, the largest member of the Engan family, has an exceptionally high number of speakers for a Papuan language, estimated to be around 160,000 (Draper $\&$ Draper 2002), and several other members of the family are also comparatively large (e.g., Huli, Kewa, the Angal group). The dialect situation is complex, and there is only moderate consensus on exactly how many distinct languages are present in the family. We include information here on Huli, Enga, Ipili, Pole, Kewa, and the Angal group. Owing to a scarcity of available data, we do not examine the other Engan languages identified by Wurm \& Hattori (1981), that is, Samberigi, Lembena, Nete, and Bisorio.

Most of the Engan languages distinguish future, present, and at least two past tenses as obligatory inflectional categories. In most tense and aspect combinations subject person and number are also marked on the verb. The inflectional and free pronominal paradigms typically show some syncretism relating to 2nd and 3rd person non-singular (see Foley 1986: 72-74, Suter 1997).

The Engan language evidential systems show some distinct tendencies, but none of these are shared across every member of the group. Except for Pole, Kewa, and Nembi, they all have a verbal inflection that expresses sensory evidence. For Huli, Enga, and Ipili there is some argument for positing a zero inflection that encodes visual or participatory-visual evidence, in opposition to this sensory marker. Many of the Engan languages make a temporal/locational distinction concerning results evidence, specifying whether or not it is observed at the same time/location as the speech event (as already seen for Duna). Only Ipili and Kewa are noted as having dedicated reportative evidentials; Enga and Angal Heneng/Henen are described as having morphemes that can be used for reports, but also have other meanings. Several of the Engan languages have

8. According to Seeland (2007a, b), the present active form of the verb 'go' would normally be mogosi, composed of the stem moga-, with a vowel change to mogo, and the present active suffix -si. However, in example (15) the verb stem does not undergo this vowel change, and the final vowel of $-s i$ is deleted. It is thus possible that, rather than being added to an inflected verb $(\mathrm{V}+\mathrm{si}+\mathrm{ai})$, the sensory marker is reanalysed as a non-segmentable regular inflection, -sai 'PRS.ACTIVE.SENS'. 
suffixes that follow TAM and/or evidential morphology and indicate whether knowledge is particular to the speaker, or shared between speaker and addressee.

3.5.2. Huli. Huli narrow evidential markers as described by Lomas (1988) and Rule $(1974,1977)$ are shown in Table 5.

Table 5. Huli evidential markers (Rule 1974, 1977; Lomas 1988, personal communication)

\begin{tabular}{|c|c|c|c|c|}
\hline $\begin{array}{l}\text { Rule/Lomas' } \\
\text { terms }\end{array}$ & $\begin{array}{l}\text { Evidential } \\
\text { category }\end{array}$ & Form & $\begin{array}{l}\text { Verbal } \\
\text { inflection? }\end{array}$ & Description \\
\hline $\begin{array}{l}\text { Sense perception } \\
\text { (Rule 1974), } \\
\text { Unseen (Lomas } \\
\text { 1988) }\end{array}$ & Sensory & $\begin{array}{l}- \text { rua, } \\
-y и a \sim \\
\text {-ауиа }\end{array}$ & yes & $\begin{array}{l}\text { "what the speaker is saying } \\
\text { is based not on visible but } \\
\text { on other sensory evidence" } \\
\text { (Lomas 1988: 124) }\end{array}$ \\
\hline $\begin{array}{l}\text { Visible evidence } \\
\text { (Rule 1977) }\end{array}$ & $\begin{array}{l}\text { Results } \\
\text { current }\end{array}$ & $=d a$ & no & $\begin{array}{l}\text { "Evidence before the } \\
\text { speaker" (Rule 1977: 52); } \\
\text { "usually used with the } \\
\text { past active tense, and } \\
\text { less commonly with the } \\
\text { past stative tense, but it } \\
\text { may also be sometimes } \\
\text { used with the future tense } \\
\text { shortened suffix -le" (Rule } \\
\text { 1974: 60) }\end{array}$ \\
\hline $\begin{array}{l}\text { Previous } \\
\text { evidence (Rule } \\
\text { 1977) }\end{array}$ & $\begin{array}{l}\text { Results } \\
\text { previous }\end{array}$ & $=y a$ & no & $\begin{array}{l}\text { "evidence which was seen } \\
\text { previously, but is now no } \\
\text { longer visible" (1977: 52); } \\
\text { "-ya is added to the rel- } \\
\text { evant past tense factual } \\
\text { statement" (Rule 1974: 60) }\end{array}$ \\
\hline
\end{tabular}

The Huli sensory evidentials are used with 3rd person subjects for events which the speaker detects "by his senses of hearing, understanding, smelling, feeling, etc." (Rule 1974: 59). ${ }^{9}$ Rule and Lomas distinguish a present sensory form -rua (16a) and a past form -yиa $\sim$-ауиа (16b). These suffixes contrast with the 3rd person present and past tense markers $-r a$ and $-y a(16 \mathrm{c})$,

9. Rule's inclusion of "understanding" in this definition suggests that the sensory markers may also indicate inferred information source for present events but we found no examples in his materials to confirm this. 
respectively (Rule 1974: 24, Lomas 1988: 124). The forms suggest that the 3rd person inflections could be compositional, following the template "TENSEEVIDENTIAL-SUBJECT", with evidentiality analyzed as either an optional category, or an obligatory category with a zero-marked visual evidential.
a. mbisigati da pia-rua
[biscuit(Eng) ?DEF burn-PRS.SENS.3]
'The biscuits are burning (can smell them).' (Rule 1974: 59)
b. abe guпипи рi-ауиа
yesterday airplane go-[PST.SENS.3]
'The airplane left yesterday (but I didn't see it).' (Lomas 1988:
124) [Spelling changed to Rule's othography by San Roque \& Loughnane]
c. Tabi andaga pi-ya
[PN home go-PST. 3]
'Tabi went home.' (Rule 1977: 77)

Huli has two results evidentials specifying inference from (physical) evidence, and indicating whether the evidence is current (Rule and Lomas' term: "visible") or previous. Rule and Lomas both analyse the results markers $=d a$ and =ya as part of a wider system of epistemic modality in Huli. They are phonologically bound forms which occur on fully inflected verbs, as in (17a, b), or on non-verbal predicates (Rule 1977: 52). The occurrence of $=d a$ with non-past verb forms is discussed in Section 4.2.
a. $\quad \grave{i} \quad k \bar{a} g u a$ gìlibi-ru=da
[1SG bad write-1SG.PST=RESU.CURRENT] 'I wrote badly (going on the evidence of the bad writing on the paper before him).' (Rule 1974: 60)
b. $\quad \underline{i} \quad k a \overline{g u a}$ gìlibi-ru=ya
[1SG bad write-1SG.PST=RESU.PREVIOUS
'I wrote badly (after having seen his bad writing in his book, and then going home without the book, and telling his parents).' (Rule 1974: 60)

Examples (17a) and (17b) have a 1st person subject and describe a presumably unintentional state of affairs; see Curnow (2002b) concerning evidentials and the expression of non-volitionality.

There are at least four other bound markers that may prove to be part of the evidential system in Huli, but require further data and investigation. The morpheme $=$ bada 'possibilitative aspect' contrasts with the results evidentials, and examples such as (18) suggest a reasoning information source meaning. 


\section{Tabi andaga pi-ya=bada \\ [PN home go-PST=POSSIBILITATIVE]}

'Tabi may have gone home (because he's not around, and the probability is that he's gone home).' (Rule 1977: 77)

Rule also mentions an "internal evidence" marker that is used with adjectives "which describe[s] how a person is feeling psychologically or physically" (Rule 1974: 53) and occurs with 1st person singular only (see also Lomas 1988: 160, 287). This may be an example of a special evidential category for subjective internal states, restricted to 1 st person because such phenomena are experienced privately and can only be indirectly observed in others (cf. Plungian's 2011 discussion of the "endophoric" evidential category).

A further past tense category identified by Rule (marked by the suffix -ne -ni) may have information source meaning. In the 1974 manuscript, Rule labels this the "historic/unseen". He describes it as primarily used "when telling a story or narrative, or relating events which took place in the distant past" (Rule 1974: 34), but also outlines an extended usage for recent events, which carries the implicature that the event was not seen. ${ }^{10}$ In the 1977 publication, Rule labels this suffix simply as "far past" (Rule 1977: 76). Rule's differing analyses highlight the connection between information source and time reference, that is, that there is a "vanishing point" where temporal distance and lack of direct perceptual access become strongly correlated (see, e.g., Dahl 1985: 123, Lazard 2001, Plungian 2011: 23, Siegl 2004).

Finally, Rule outlines a "past stative" form of existential verbs which "is frequently used in the 3 rd person to denote that one or more people or things were at a certain place previously" (Rule 1974: 33). This description and the examples Rule provides are suggestive of a visual stative marker, encoding that a situation was seen prior to the time of utterance (cf. Duna =rua, Table 3).

3.5.3. Enga. Enga has "suffixes that indicate the speaker's attitude to a particular event, concept, or object, whether and what he can deduce, sense, etc. about the epistemological/ontological status of that event, concept, or object" (Lang 1973: xlii). Bound morphemes in Enga that make some reference to information source are shown in Table 6. More data are needed to confirm the distinction of results and reasoning as narrow evidential categories. For the pur-

10. Rule states that "[w]hen the speaker is speaking about a recent event which he did not see going on, but he knows from previous knowledge that it has gone on, then he uses the historic/unseen past tense, even of things which took place the same day" (Rule 1974: 34). The Huli examples Rule provides (which include several question-and-answer pairs) suggest that $-n i \sim-n e$ may in fact indicate "not seen by speaker AND/OR hearer", depending on sentence type and pragmatic context. 
Table 6. Enga evidential markers (from Lang 1973 and Draper \& Draper 2002)

\begin{tabular}{|c|c|c|c|c|}
\hline $\begin{array}{l}\text { Lang/Draper \& } \\
\text { Draper's terms }\end{array}$ & $\begin{array}{l}\text { Evidential } \\
\text { category }\end{array}$ & Form & $\begin{array}{l}\text { Verbal } \\
\text { inflection? }\end{array}$ & Description \\
\hline $\begin{array}{l}\text { Suffix for sensing } \\
\text { (Lang 1973) }\end{array}$ & Sensory & $\begin{array}{l}-l u \\
\text { (Enga) }\end{array}$ & yes & $\begin{array}{l}\text { "evidence perceived by the } \\
\text { senses with the excep- } \\
\text { tion of vision. [...] The } \\
\text { tense of the sensing is the } \\
\text { same of that of the ac- } \\
\text { tions sensed [...] One may } \\
\text { not sense into the future." } \\
\text { (Lang 1973: xliii) }\end{array}$ \\
\hline $\begin{array}{l}\text { Deductive (Lang } \\
\text { 1973), evidential } \\
\text { suffixes (Draper } \\
\& \text { Draper 2002) }\end{array}$ & Results & $\begin{array}{l}\text { lámo } \\
\text { (Enga), } \\
\text {-lamo } ~ \\
\text {-lyamo } \\
\text { (Kyaka) }\end{array}$ & no & $\begin{array}{l}\text { "indicate[s] that something } \\
\text { has later been noticed, has } \\
\text { become evident or real- } \\
\text { ized." (Draper \& Draper } \\
\text { 2002: 61); "there is solid } \\
\text { evidence for it" (Lang } \\
\text { 1973: xlii) }\end{array}$ \\
\hline $\begin{array}{l}\text { Suffix for sensing } \\
\text { (Lang 1973) }\end{array}$ & Reasoning & $\begin{array}{l}\text { lumu } \\
\text { (Enga) }\end{array}$ & no & $\begin{array}{l}\text { "based on a combination } \\
\text { of the information sup- } \\
\text { plied by someone else and } \\
\text { one's own past experi- } \\
\text { ence" (Lang 1973: xlii) }\end{array}$ \\
\hline $\begin{array}{l}\text { Suffix for tales } \\
\text { (Lang 1973) }\end{array}$ & Reported & $\begin{array}{l}=\text { lámi } \\
\text { (Enga) }\end{array}$ & no & $\begin{array}{l}\text { "indicates that the event re- } \\
\text { ported on is a tale, legend } \\
\text { or myth" (Lang 1973: xlii) }\end{array}$ \\
\hline
\end{tabular}

poses of this survey we have grouped Kyaka Enga with Enga (see also Foley 1986: 238).

The sensory affix - $l u$ precedes obligatory tense and person suffixes, and can be used in describing past or present time events. Lang notes that, for the sensory inflection, "the sensing is done in the first person while the action sensed must be non-first" (1973: xliii). That is, the perceiver of evidence is identified as the speaker, while the subject of the main predicate event must be 2nd or 3rd person. A partial exception to this is in descriptions of feeling and emotion, where the sensory evidential can ONLY be used with 1st person experiencer subject arguments (Lang 1973: liii). This latter pattern somewhat parallels the distribution of the Huli "internal evidence" marker (Section 3.5.2).

Lang (1973: xlii) suggests that the marker lámo can be used to express hearsay as well as results evidence, but provides no examples illustrating this analysis. She also describes a suffix -pyáa, which indicates that "the event took place in the past and the speaker did not witness it. Usually the events are so 
far in the past that there can be no living witness" (1973: xliii). It remains to be seen whether this morpheme should be understood as primarily encoding temporal or information source features (or both).

3.5.4. Ipili. Ipili (or Ipili-Paela) is spoken by approximately 26,000 people living in the Porgera and Paela valleys; see Borchard \& Gibbs (2011) for further location and dialect information. Ipili evidentials, as identified by Terence Borchard (e-mail communication, January 2011) and Frances Ingemann (2011 and e-mail communication, January 2011 and April 2012), are shown in Table 7.

Examples of Ipili evidentials are shown in (19-21). The interlinear glosses, morpheme boundaries, and explanations are as supplied by Borchard, with some additional input from Ingemann, and San Roque \& Loughnane.

The sensory inflection is exemplified in (19), a description of a present time event that is aurally perceived (e.g., the speaker has heard the pig squealing, followed by a thump and then silence). Ingemann (e-mail communication, April 2012) confirms that this inflection is also used for other sensory experience, for example cold and hunger.

Table 7. Ipili evidential markers (from Borchard e-mail communication, Ingemann 2011)

\begin{tabular}{|c|c|c|c|c|}
\hline Borchard's term & $\begin{array}{l}\text { Evidential } \\
\text { category }\end{array}$ & Form & $\begin{array}{l}\text { Verbal } \\
\text { inflection? }\end{array}$ & Description \\
\hline Sensed & Sensory & $-l u(a)$ & yes & $\begin{array}{l}\text { "based on hearing" } \\
\text { (Borchard) }\end{array}$ \\
\hline Visible Evidence & $\begin{array}{l}\text { Results } \\
\text { Current }\end{array}$ & $=y a$ & no & $\begin{array}{l}\text { "seeing physical evi- } \\
\text { dence" (Borchard) }\end{array}$ \\
\hline $\begin{array}{l}\text { Previously Visible } \\
\text { Evidence }\end{array}$ & $\begin{array}{l}\text { Results } \\
\text { Previous }\end{array}$ & $=y a l a$ & no & $\begin{array}{l}\text { "previously visible evi- } \\
\text { dence” (Borchard) }\end{array}$ \\
\hline Reported Speech & Reported & $=(e) p i a$ & no & $\begin{array}{l}\text { "reporting what some- } \\
\text { one else told [the } \\
\text { speaker]" (Borchard); } \\
\text { "added to remote past } \\
\text { inflections to indi- } \\
\text { cate that the speaker } \\
\text { does not know of the } \\
\text { event from personal } \\
\text { knowledge" (Ingemann } \\
\text { 2011) }\end{array}$ \\
\hline
\end{tabular}




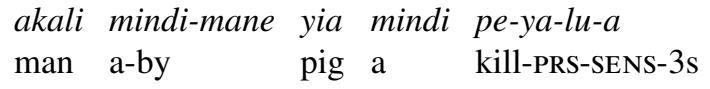

Results and reported evidence markers are applied following tense and person inflections. Example (20a) shows the current results marker, and would be appropriate to say while at the location where the pig-killing took place. Example (20b) would be used when the speaker has left that location, and is reporting on the event to someone else.

a. akali mindi-mane yia mindi pe-yal-a=ya man a-by pig a kill-NRP-3SG=RESU.CURRENT 'A pig has been killed by someone. (I infer from visible evidence.)' (Terence Borchard, e-mail communication)

b. akali mindi-mane yia mindi pe-yal-a=yala man a-by pig a kill-NRP-3SG=RESU.PREVIOUS 'A pig has been killed by someone. (I inferred from visible evidence.)' (Terence Borchard, e-mail communication)

The reported marker =epia (perhaps cognate with Enga -pyáa) is exemplified in (21a), contrasting with (21b), which is evidentially unmarked. Borchard indicates that the lack of an overt evidential often implies that the speaker saw the event in question (see also (22)). This supports analyzing Ipili as having a zero-marked participatory-visual evidential category.

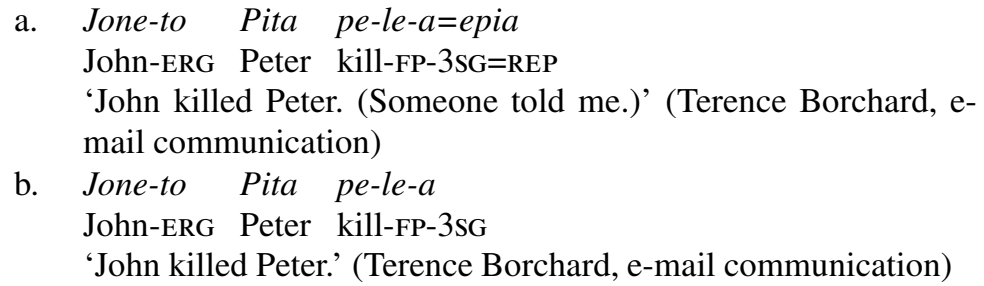

Ingemann (e-mail communication, January 2011) further remarks that, although Ipili evidential markers are most common with 3rd person singular subjects, they do occasionally occur with other persons; occurrence with a 1 st person subject is probably restricted to things that the speaker performs unconsciously.

Borchard describes two other Ipili forms that are relevant to broad evidentiality. A phonologically independent form yalua (cf. Duna sensory =yarua) indicates "some level of conjecture or doubt about what is being said". It can be used in non-verbal as well as verbal clauses and is usually sentence final. 
The morpheme =koni, which follows an inflected final verb, indicates "common knowledge". This might be used, for example, when reminding the hearer of an event that both they and the speaker had seen, as in (22).

Jone-to Pita pe-le- $a=k o n i$

John-ERG Peter kill-FP-3sG=COMMON.KNOWLEDGE

'John killed Peter. (You remember, we both saw it.)' (Terence Borchard, e-mail communication)

Although there is no apparent formal similarity, the function of $=k o n i$ is similar to non-inflectional suffixes found in Duna, Pole, and the Angal group, in that it is concerned with an evaluation of knowledge as individual or shared.

3.5.5. Pole. Pole (Erave) has two results evidentials that attach to inflected verbs and adjectives (Table 8 ). These specify that the speaker has deduced the main predicate activity from (physical) evidence, and indicate whether the evidence is current (Rule's term is "visible") or previous; see Rule (1977: 52, 53, 81) for exemplification of these forms.

Table 8. Pole evidential verbal affixes (from Rule 1977)

\begin{tabular}{lllll}
\hline Rule's term & $\begin{array}{l}\text { Evidential } \\
\text { category }\end{array}$ & Form & $\begin{array}{l}\text { Verbal } \\
\text { inflection? }\end{array}$ & Description \\
\hline Visible evidence & $\begin{array}{l}\text { Results cur- } \\
\text { rent }\end{array}$ & $=n a$ & no & $\begin{array}{l}\text { "evidence before the } \\
\text { speaker" (Rule 1977: } \\
\text { Previous evidence }\end{array}$ \\
$\begin{array}{l}\text { Results } \\
\text { previous }\end{array}$ & $=y a$ & no & $\begin{array}{l}\text { "evidence which was } \\
\text { seen previously, but is } \\
\text { now no longer visible" } \\
\text { (Rule 1977: 52) }\end{array}$ \\
\hline
\end{tabular}

According to Rule (1977: 79-80), Pole has an additional inflectional paradigm used in the "stative voice". His description of past tense stative voice forms is suggestive of a visual-sensory evidential category, as he includes an example in which auditory evidence is clearly implicated, and notes that the occurrence of stative past forms with 1st person subjects is partially restricted to involuntary predicates. ${ }^{11}$ These verb forms (and the contrasting "active voice"

11. "The past stative tense has quite a particularized area of usage. It is used under the following conditions: i) When the action was performed by the speaker on behalf of someone else, when it has the benefactive idea. ii) When the action being described was performed by the speaker, but without his conscious participation, but was rather carried out by one of his faculties, e.g. forgetting, losing, falling over, etc." (Rule 1977: 80). 
forms, which could potentially have participatory information source meaning) require further investigation.

Rule also describes (but does not exemplify) the Pole "referential aspect" marker -nde, which he identifies as belonging to the same set of suffixes as the results evidentials, and defines as follows: "The referential aspect is used with the near and far past tenses when referring to, or reminding the person spoken to of, an event which they both saw" (Rule 1977: 80). This would appear to encode two separate facets of evidence, specifying that it belongs to a visual category, and is shared by speaker and hearer.

3.5.6. Kewa. Franklin \& Franklin (1978) describe two evidential markers in Kewa that are applied to inflected verbs (past tenses only), shown in Table 9. These are defined as indicating "reported seen aspect" (23a) and "reported unseen aspect" (23b).

Table 9. Kewa evidential markers (from Franklin \& Franklin 1978, Franklin 1964)

Franklin \& Franklin's terms

$\begin{array}{lll}\begin{array}{l}\text { Evidential } \\ \text { category }\end{array} & \text { Form } & \begin{array}{l}\text { Verbal } \\ \text { inflection? }\end{array}\end{array}$

Reported seen aspect (Franklin \& Franklin

Visual $=n a \quad$ no

1978), observed aspect (Franklin 1964)

Reported unseen aspect (Franklin \& Franklin Reported =ya no

1978), unobserved aspect (Franklin 1964)

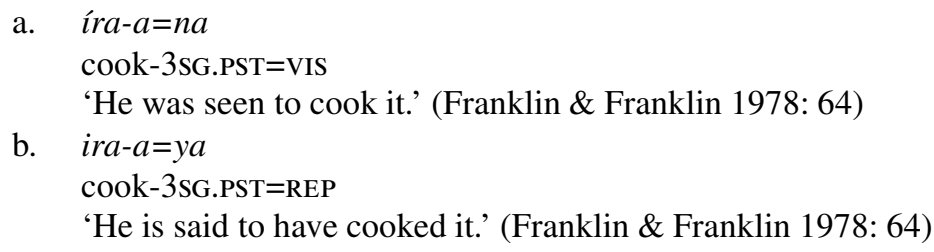

The most straightforward interpretation from the examples given is of a visual and a reported category, but further data are needed to confirm this. Interestingly, the Kewa evidential forms appear to be identical to those of Pole, but with quite different semantics.

3.5.7. The Angal group. The language(s) Angal Heneng, Angal Henen, and Angal Enen are labelled in this article as "the Angal group". ${ }^{12}$ These

12. The Angal varieties are also known as the following: Angal Heneng as West Mendi, West Angal Heneng, and Wola; Angal Henen as Mendi, North Mendi, Angal, and East Angal; and Angal Enen as South Mendi, South Angal Heneng, and Nembi. 
speech varieties are located in a cluster in and around the town of Mendi, towards the eastern edge of the known evidentiality area. Their status as distinct languages remains unclear (see Reithofer 2011). We present data on Angal Heneng (specifically, the Aklal Heneng dialect, from Reithofer, personal communication, 2006) and Angal Henen (from Madden no date) together, as their evidential systems appear to be very similar. The Angal Enen (Nembi) material (from Tipton 1982) is presented at the end of this section.

Evidentiality is an important category of verbal inflection in the Angal group, but the systems are at present not well understood and the analysis suggested here requires confirmation and expansion. The categories described for Angal Heneng and Angal Henen are shown in Table 10.

"Unseen" and "part seen" inflections occur with present, near-past and distant-past tenses (Madden no date). The "unseen" may represent a participatory evidential category that includes factual semantics but excludes visual evidence. It is commonly used in describing factual existence, especially of items that closely concern the speaker, as shown in (24) from Aklal Heneng.

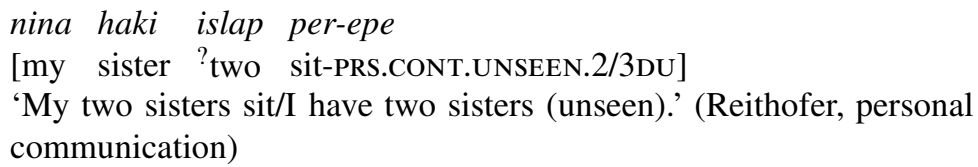

Madden's "heard aspect" (including sensory, results, and reported evidence; Reithofer, personal communication) occurs with present tense only (Madden no date). "Evidence aspect" (i.e., results) can occur with both the near past and the distant past inflections. Reithofer also provided a future tense example (25) from Aklal Heneng.

ssei epola $=i$

[rain come.FUT.3sG=RESU]

'I can tell from signs (sun, clouds) that it will rain.' (Reithofer, personal communication)

Although the exact semantic and formal contrasts of the system(s) are unclear, features concerning symmetry of speaker and hearer information source appear to be an integral part of grammaticized evidentiality in Angal Henen, as illustrated in the contrast between the two results markers, $=s a$ and $=e$, and probably the Angal group as a whole (see also Sillitoe no date). Madden further describes a morpheme $=n d a(\mathrm{cf}$. Pole $=n d e)$ that is part of the Angal Henen "aspect of perception" (i.e., evidential) system and which can be added to near and far past verbs, indicating that the speaker and addressee share knowledge of the described event. For example, when added to a verb inflected for near past tense and visual evidence "the suffix $=n d a[\ldots]$ shows that вотн the person speaking and the person spoken to saw the action being done" (Madden no 


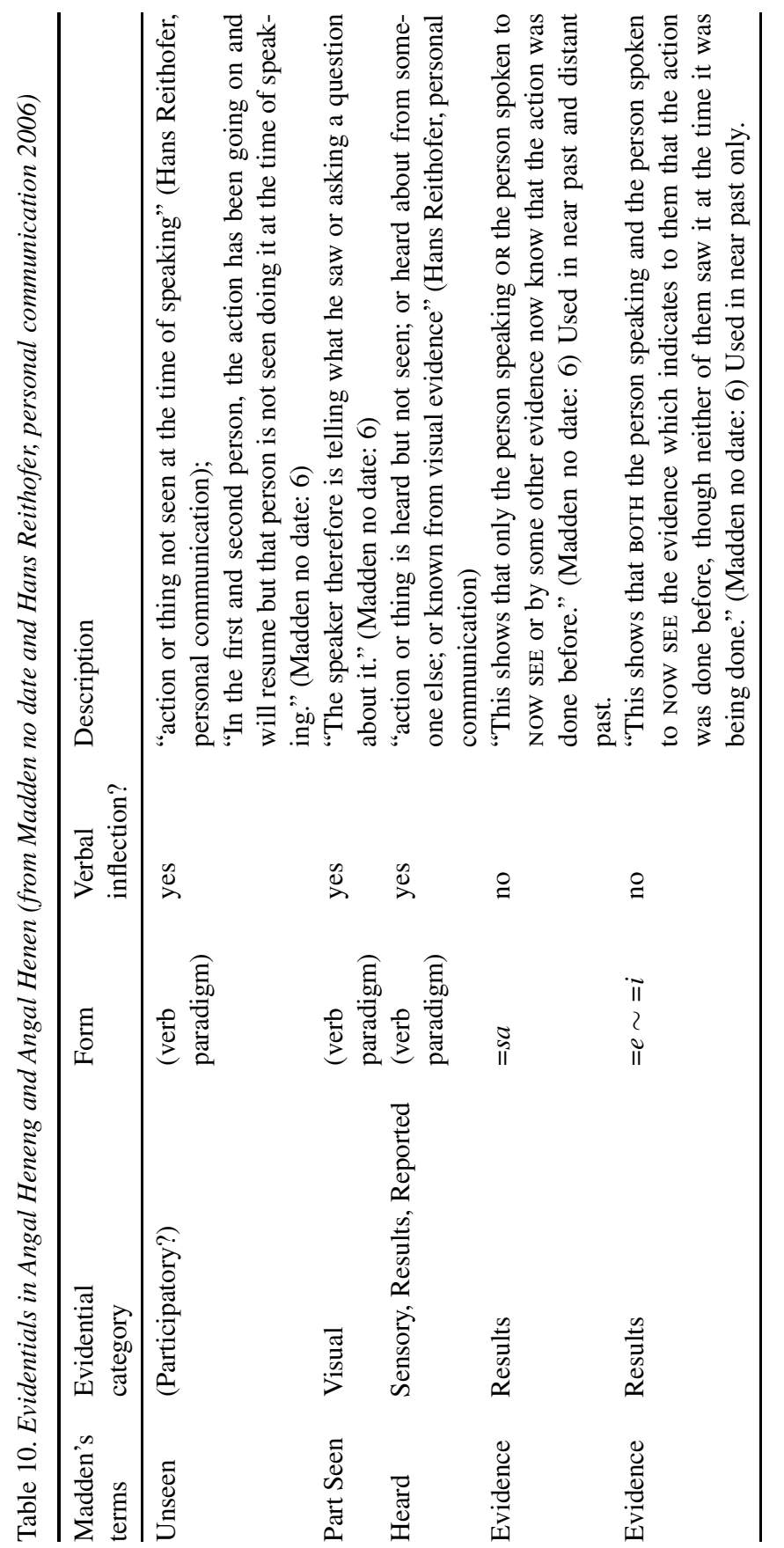


date: 6). Additionally, $=n d a$ can follow the results evidence morpheme $=s a$ on far past verb forms, presumably marking that the evidence for the event is (or was) observed by both speaker and hearer (note that for near past verbs, this function is covered by $=e \sim=i$ ). Madden indicates that individual versus joint access to evidence is also marked within the sensory category, but no examples are provided.

Angal Enen (Nembi) has an evidential distinction expressed in portmanteau verbal suffixes in the present and past tenses, described by Tipton (1982: 7879) as follows:

Customary, present, and past tense endings are also inflected for degree of perception. Greater perception means that both speaker and hearer have participated in or witnessed the event, whereas lesser perception means that either speaker, hearer, or both[,] neither participated in nor witnessed the event.

Nembi evidentiality thus seems to encode direct (participatory/visual and possibly sensory) versus indirect information source, with a cross-cutting distinction concerning shared speaker/hearer experience. However, no examples of the relevant verb forms have as yet been located in Tipton's materials, and we do not include the Nembi categories in further comparative discussion.

\subsection{Foe}

Foe (Foi) belongs to the East Kutubu "family", and is spoken in Southern Highlands Province, around and to the east of Lake Kutubu. The classification as Trans New Guinea remains preliminary (Ross 2005). The other posited extant member of this family is Fiwaga (Wurm \& Hattori 1981), which is also a village and clan name (Weiner 2001, Kini 2010) and may be considered a dialectal variety of Foe. Franklin (2001) comments that, although genetic relatedness must be very distant, there is a high amount of lexical and sound correspondences between Foe, Fasu (Section 3.7), and certain Engan languages.

In Foe, "the speaker indicates by the particular verb suffix which he uses, the means whereby he has become aware of the event about which he is talking" (Rule 1977: 71). These evidential suffixes are added directly to the verb root and are portmanteau forms which also indicate tense (present, near past, far past, or future).$^{13}$ Five categories of evidentiality ("verbal aspects" in Rule's terms) are distinguished, with a further current/previous time distinction within the results category, as shown in Table 11. The future paradigm

13. Rule (1977: 74) notes that Joan Rule attempted further morphemic analysis and subdivision of these suffixes in her MA thesis on the Foe language, but that this necessitated such a complex list of rules of occurrence that it did not simplify the description (nor, presumably, elucidate the system). 


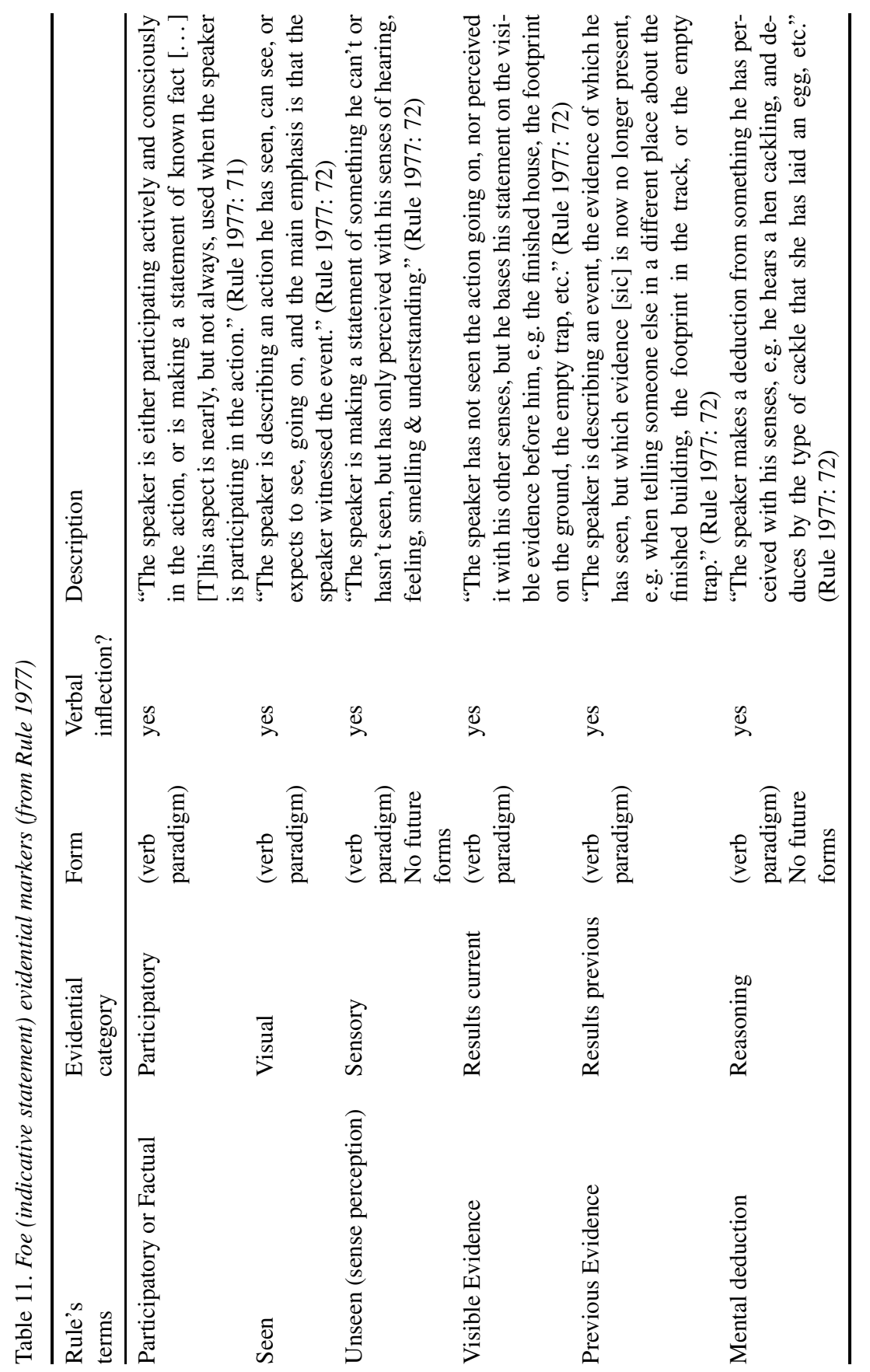


lacks sensory and reasoning forms, and there is some syncretism in the present tense paradigm (the participatory and results previous categories share the same form, as do visual and results current).

The Foe evidential morphemes are each exemplified in Rule (1977: 37, 7477). Similar (but not identical) markers with evidential meanings also occur on adjectival predicates (Rule 1977: 52) and noun or gerundial phrases (Rule 1977: 97).

Rule, and his wife and colleague Joan Rule, lived for many years within the Foe community, and spoke the language fluently. His description of the Foe system is concise but sensitive to usage practices. He notes that visual evidentials are typically used in describing the actions of 2 nd and 3rd persons, but "can also be used of something the speaker is doing or has done if he has not been doing it deliberately or consciously, and only becomes conscious of it subsequently. This includes things the speaker has seen in a dream" (Rule 1977: 72).

\subsection{Fasu}

Fasu (the only identified member of the West Kutubu family) is spoken in Southern Highlands Province, to the west of Lake Kutubu. Like the East Kutubu "family", West Kutubu is only tentatively classified as Trans New Guinea (Ross 2005). Fasu has a number of morphemes that reference information source, referred to by Loeweke \& May (1980) as "speaker viewpoint suffixes". At least some of these morphemes can be used in combination with each other (Loeweke \& May 1980: 96), showing that they do not form a single paradigm. Our analysis of the grammatical status of these morphemes contrasts somewhat with the analysis of Loeweke \& May. We analyse at least two sets of evidential morphemes: (i) the past participatory and visual-sensory categories, and probably also the present visual category, which are part of the verbal inflectional paradigm and occupy the same slot as other TAM inflections; and (ii) sensory (heard) and reported markers, which are not verbal inflections but which occur on verbs or other parts of speech.

Loeweke \& May describe the past tense markers shown in the first row in Table 12 as having participatory semantics. These markers occur in paradigmatic opposition to the visual-sensory verbal inflections, and we analyse them as participatory evidentials. The participatory and visual-sensory inflections occur in the same slot of the verb and require a mood marker following them. ${ }^{14}$ Some

14. In Fasu, final verbs generally require a bound form in addition to verbal inflection. This may be a mood markers (e.g., -po 'statement', -re 'question') and/or one of the non-inflectional evidential markers shown in Table 12. In regard to the form of the Fasu visual/sensory inflections, an immediate question is whether they are compositional, formed from a visual/sensory suffix - raka- in combination with a general (and, in fact, non-evidential) past tense inflec- 


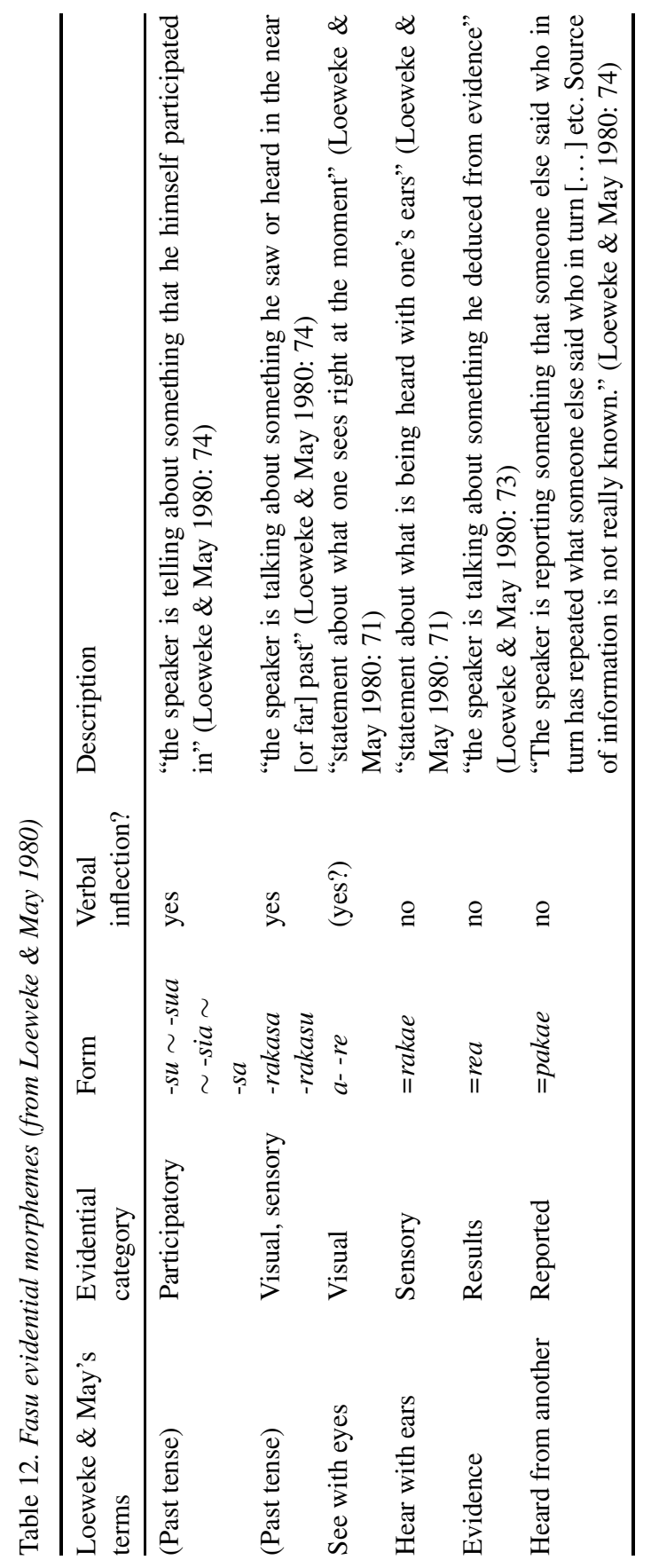


examples suggest that the Fasu participatory category also incorporates factual semantics. Examples are shown in $(26 a, b)$, where the participatory and visual-sensory past tense markers, respectively, precede the negative suffix $-f a$.

a. ano pu-sua-fa-po

I gO-PST.PCP-NEG-STATEMENT

'I did not go.' (Loeweke \& May 1980: 74)

b. nomo apea pe-rakasa-fa-po

my house come-PST.VIS/SENS-NEG-STATEMENT

'He didn't come to my house.' (Loeweke \& May 1980: 67)

Fasu also has what appears to be a visual marker in the present tense. This construction is very unusual for the area in that it is circumfixal (rather than suffixal/encliticized). The only example of this form as yet noted in the available data is given in (27), and its grammatical status remains unclear.

\section{a-pe-re}

VIS-come-VIS

'I see it coming.' (This is said when actually seeing the airplane on the horizon.) (Loeweke \& May 1980: 71)

Loeweke \& May describe the Fasu sensory marker =rakae (and the inflection -rakasu) as relating to hearing, but, as is the case for Bogaia (Section 3.4.3), there is no evidence available concerning their use with other senses, and we treat them as general non-visual sensory forms. Unlike the participatory and visual-sensory past tense forms, the sensory evidential =rakae appears to be used in combination with preceding verbal inflection (28), and we classify it as non-inflectional. Because of their formal similarity it seems very likely, however, that the past visual-sensory and present sensory markers are at least diachronically related.

pe-ra=rakae

come-customary $=$ SENS

'I hear it coming.' (This is said when hearing an airplane before seeing it.) (Loeweke \& May 1980: 71)

\footnotetext{
tion $-s a \sim-s u$. In this case, we would posit a general template of VERB-EVIDENCE-TENSE, with zero-marked participatory evidence. However, this analysis does not account for why the wider variety of past allomorphs do not occur following -raka- (a conditioned labialization/palatalization analysis explains only some of the data), nor why -raka- would only occur with past tense verb forms, nor why Loeweke \& May make no such suggestion of compositionality. As such, it offers few advantages to a non-compositional understanding of the morphemes; see also Footnote 13.
} 
At least some of the non-inflectional evidential forms in Table 12 can occur in combination with the participatory or visual-sensory past tense inflections, for example as in the -sua=pakae combination shown in (29).

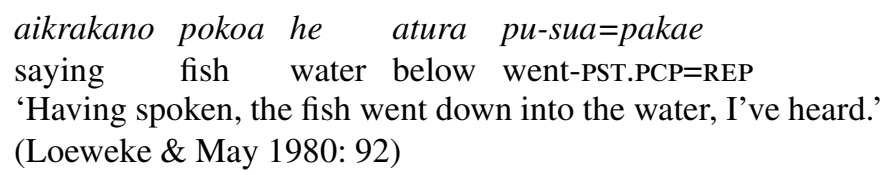

In textual examples the form =ripo (30) appears to be used as a quotative index, serving the grammatical function of marking a complement clause of a verb of speech.

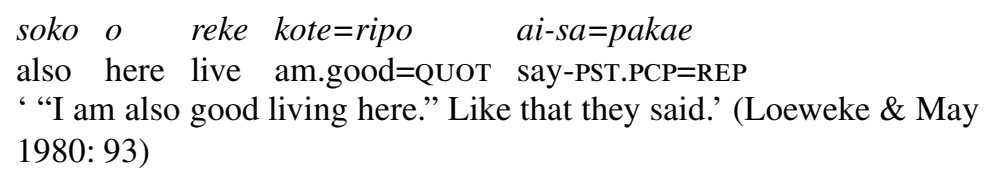

However, it is described by Loeweke \& May as also having a reported function: "the speaker is reporting something that he heard from the original speaker or something that is self evident. The source of information is known" (Loeweke \& May 1980: 74). For the purposes of this survey we do not treat =ripo as an evidential, as it seems likely that the reported meaning is an extension of its grammatical function. ${ }^{15}$

Also relevant to broad evidentiality is the verbal affix -hoapo: "the speaker is repeating something he told you or is telling you something that is obvious" (Loeweke \& May 1980: 74). The bound morpheme - pi (cf. Duna particle pi) indicates that "the speaker is reporting his thoughts", and may prove to be narrowly evidential upon further investigation. Loeweke \& May (1980: 72) also describe a distinction in imperative forms in Fasu as marking whether or not the speaker expects to actually see their command carried out. These forms are -sie "command, present tense, in sight" and -nie "command, future tense, out of sight". A visual evidential distinction in commands would be typologically quite unusual (see Aikhenvald 2004: 250-253), and more information is needed to test this interpretation of the imperative contrast. ${ }^{16}$

15. Note that some researchers (e.g., Oswalt 1986, Aikhenvald 2004) also distinguish "quotative" evidentials. In this article we use the term "reported" as a general category label for such markers (except when citing other authors), following Willett (1988). We treat quotative indexes as distinct from reported category evidential markers (see Güldemann 2008).

16. The majority of languages discussed in this survey have two distinct (inflectional or constructional) sets of imperative markers; see Gossner (1994: 49), Franklin (1971: 39), Giles (no date: LL1), Lang (1973: xxxvi), Loeweke \& May (1980: 72), Madden (no date: 16), Rule (1977: 55-58), San Roque (2008), and Schieffelin (1985: 567). Rather than a distinction of visibility 


\subsection{Bosavi family}

3.8.1. Bosavi overview. The Bosavi language family includes eight languages (Lewis (ed.) 2009), with speaker groups in the hundreds or low thousands, located along the southwest edge of the evidentiality area. The homelands of these groups are in Southern Highlands and Western provinces, moving out of the highlands and onto the Great Papuan Plateau. The word Bosavi is also used as an indigenous term that refers to the Kaluli, Ologo, Walulu, and Wisesi dialects/cultural groups (Schieffelin 1990: 2).

Generally, Bosavi languages have little to no person or number marking on the verb, ${ }^{17}$ but otherwise show typical Trans New Guinea features such as medial and final clause distinctions and $(\mathrm{S})(\mathrm{O}) \mathrm{V}$ word order. At least three Bosavi languages, Kaluli, Edolo, and Onabasulu, have grammaticized evidentiality. According to Logan (2008), Kasua does not have evidential marking, and little information is currently easily available on other languages classified as Bosavi (Aimele, Beami, Dibiyaso, and Sonia). ${ }^{18}$

3.8.2. Kaluli. Kaluli is spoken by approximately 2000 people living north of Mt Bosavi. Sources we have consulted on the language are Grosh \& Grosh (2004), Rule (no date), Schieffelin \& Feld (1998), and Schieffelin (1985, 1990, 1996). These researchers identify at least two (simplex) morphemes that narrowly specify information source (Table 13). Other narrow evidentials are also identified by Grosh \& Grosh (2004), but the available descriptions diverge. We do not include these latter morphemes in Table 13, or in the comparative discussion in Section 4.

Examples of the sensory evidential $=o: m$ are scarce in the available sources. Rule (no date) describes this morpheme as a "second position suffix" that attaches to inflected verb forms. It is appropriate to at least aural and olfactory perception (31), but is not usually employed for talking about internal bodily experience (Rule no date: 33; Bambi Schieffelin, personal communication).

as suggested by Loeweke \& May for Fasu, these contrastive imperatives are generally characterized as encoding a time distinction of "immediate" (do X right now!) versus "deferred" (do $X$ later). The extent of a paradigmatic immediate/deferred imperative distinction in languages of the wider region has not been thoroughly investigated, but it is quite intriguing that a comparable distinction is attested in several North American languages (Mithun 1999: 172, 182), where grammaticized narrow evidentiality is common, and in Nambikuara (Kroeker 2001: 30-32). See also Aikhenvald (2010: 128-131), Bybee (1985), Palmer (2001: 82) concerning delayed imperatives more generally.

17. Gossner (1994: 36) lists the possible existence of 1st and 3rd person verbal inflection in Edolo, but these were not found in the texts or examples given.

18. Shaw's (1986) classification included a further subgrouping of several other languages within the Bosavi family, but these are now generally classified separately as "East Strickland". 
Table 13. Kaluli evidential markers (from Grosh \& Grosh 2004, Rule no date, Schieffelin 1996)

\begin{tabular}{|c|c|c|c|c|}
\hline $\begin{array}{l}\text { Researchers' } \\
\text { terms }\end{array}$ & $\begin{array}{l}\text { Evidential } \\
\text { category }\end{array}$ & Form & $\begin{array}{l}\text { Verbal } \\
\text { inflection? }\end{array}$ & Description \\
\hline $\begin{array}{l}\text { 2nd position aspect } \\
\text { suffix (Rule no } \\
\text { date) }\end{array}$ & Sensory & $=o: m$ & no & $\begin{array}{l}\text { "speaker's assertion is } \\
\text { based on deduction or } \\
\text { inference from something } \\
\text { sensed aurally or through } \\
\text { other senses, but without } \\
\text { attribution of a PARTICU- } \\
\text { LAR source" (Schieffelin } \\
\text { 1996: 441; emphasis in } \\
\text { original) }\end{array}$ \\
\hline $\begin{array}{l}\text { Observed action } \\
\text { (Grosh \& Grosh } \\
\text { 2004), second } \\
\text { position aspect } \\
\text { suffix (Rule no } \\
\text { date) }\end{array}$ & Results & $=l o: b$ & no & $\begin{array}{l}\text { "speaker's assertion is } \\
\text { based on visible/visual } \\
\text { evidence that can be shared } \\
\text { by addressee" (Schieffelin } \\
\text { 1996: 441); "added when } \\
\text { the speaker is basing his } \\
\text { statement on PRESENT } \\
\text { VISIBLE EVIDENCE" (Rule } \\
\text { no date: 30; emphasis in } \\
\text { orginal) }\end{array}$ \\
\hline
\end{tabular}

$$
\begin{aligned}
& \text { kabo kugu-wo: dowa=yo:m } \\
& \text { [domestic.pig 'smell-TOP be/have.'PRS=SENS] } \\
& \text { 'There's a pig smell around.' (Rule no date: } 30 \text { ) }
\end{aligned}
$$

The Kaluli marker $=l o: b$ is added following tense/aspect inflection. Examples and descriptions emphasize that $=l o: b$ marks newly acquired, but now obvious, information. The available sources agree that what is crucial to the morpheme's use is the availability and/or visibility of present evidence. In all the verbal examples noted so far, $=l o: b$ is used in describing a non-present time activity, as in (32).

$$
\begin{aligned}
& \text { nulu-wo: ho: } n-o: \quad \text { mõda } \quad \text { sidd-abe=lo:b } \\
& \text { [night-? water-TOP many ?-PST.2/3=VIS] } \\
& \text { 'In the night much rain fell.' (It is clear from water on the ground.) } \\
& \text { (Rule no date: } 30 \text { ) }
\end{aligned}
$$

As can be seen from the descriptions in Table 13, =lo: $b$ appears to encode both visual and results semantics. As the available verbal examples involve in- 
ference after the event rather than contemporaneous observation (e.g., 'I saw it rain'), we classify it as representing a results category. ${ }^{19}$ Further data concerning whether $=l o: b$ also occurs with present tense verb forms (e.g., 'I see it is raining') will test this analysis. Schieffelin (1985: 586) indicates that $=l o: b$ does not occur with 1 st person subjects.

Grosh \& Grosh (2004) describe two further suffixes for Kaluli, -(l)ale and -(o:)lo:bo:, which they characterize as narrow evidentials. ${ }^{20}$ Textual and other examples provided suggest that if -ale does refer to information source, it represents a visual-sensory category, used for describing past events that the speaker has directly witnessed. Examples of -lobo: suggest that it marks indirect (results and/or reported) evidence; this form is presumably related to $=l o: b$. Rule (no date) and Schieffelin $(1985,1996)$ do not include -ale or -lo:bo: in their descriptions of Kaluli evidentials and we do not discuss these morphemes further in this article.

Schieffelin (1996) further describes a rich array of Kaluli strategies for marking evidentiality that do not fall under the scope of this survey as they are phrasal and/or concerned with broad rather than narrow evidential semantics. Of particular interest are two recently introduced forms, one derived from Tok Pisin hia 'here', which is typically used for visually accessible evidence, and the other a new construction for talking about written evidence.

3.8.3. Edolo. Edolo has a distinction in the verbal morphology marking visual and sensory (auditory) evidence, and also a reported clitic (Table 14).

Examples of the visual (33a), sensory (33b), and reported (33c) evidential markers are given below. The visual and sensory evidentials contrast with a past inflection, $-i$. Gossner includes several examples of this past form with

19. Rule (no date) and Grosh \& Grosh (2004) point out that $=l o: b$ can be applied to adjectival predicates describing present states, which do not appear to support an inferential reading. However, according to Rule (no date: 32 ) adjectives must be inflected with the past "aspect" marker before $=l o: b$ is applied. Thus, results meaning could still be relevant in that the item in question is now observed to have, e.g., 'become big', 'become yellow', etc. Grosh \& Grosh (2004) further mention that $=l o: b$ can apply to nominal predicates, but we have not located any examples of this.

20. Grosh \& Grosh (2004) describe both -(l)ale and -(o:)lo:bo: as "reported action" suffixes, "used when the speaker does not have first hand information but is telling the story based on information which was reported to him" (2004: 27). Textual and other examples alternatively support an analysis that -ale marks visual-sensory information source. The confusion with a reportative category may be because -ale is quite common on verbs of speech where the speaker was witness to the utterance, as in (i).

iliyo: ne-mo:-yo: o:li-aom dabu bad-ale
3PL.FOC 1SG-DAT-TODP okay-similarly hear say-ale
'They asked me if I was okay.' (Grosh \& Grosh 2004: 94) 
Table 14. Edolo evidential markers (from Gossner 1994)

\begin{tabular}{|c|c|c|c|c|}
\hline $\begin{array}{l}\text { Gossner's } \\
\text { terms }\end{array}$ & $\begin{array}{l}\text { Evidential } \\
\text { category }\end{array}$ & Form & $\begin{array}{l}\text { Verbal } \\
\text { inflection? }\end{array}$ & Description \\
\hline $\begin{array}{l}\text { Visual } \\
\text { evidence }\end{array}$ & Visual & - sio & yes & $\begin{array}{l}\text { "the bound morpheme -sio, mark- } \\
\text { ing "visual evidence"" (Gossner } \\
\text { 1994: 53) }\end{array}$ \\
\hline $\begin{array}{l}\text { Evidence } \\
\text { heard }\end{array}$ & Sensory & $\begin{array}{l}\text {-sabeo } \\
\sim \\
\text {-wabeo } \\
\sim \\
\text {-habeo }\end{array}$ & yes & $\begin{array}{l}\text { "There is a second morpheme - } \\
\text { sabeo that also seems to mark "evi- } \\
\text { dence heard" " (Gossner 1994: 53) }\end{array}$ \\
\hline $\begin{array}{l}\text { Hearing, } \\
\text { he said }\end{array}$ & Reported & $=w a b u$ & no & $\begin{array}{l}\text { "The most frequent and easiest } \\
\text { to analyze of the evidentials is } \\
\text { sentence-final wabu [...] used very } \\
\text { commonly in traditional stories and } \\
\text { in conversation when one person } \\
\text { repeats what another person has } \\
\text { just said" (Gossner 1994: } 83-84 \text { ) }\end{array}$ \\
\hline
\end{tabular}

2nd and 3rd person subjects (see, e.g., Gossner 1994: 27, 31, 32, 44), arguing against interpreting $-i$ as a participatory category evidential.
a.
amalahilä ilia gähëö siabulu amolä PRO.VERB.SEQ 3PL.ERG pandanus sweet.potato that.COMIT gia-sio cook-VIS
'So then they cooked pandanus and sweet potato together (I saw).' (Gossner 1994: 53)
b. waibo amo widaea sale-lo galö-wabeo black.palm that cassowary.ERG fill.up-IRR narrate-SENS 'Cassowaries eat that black palm, he said.' (Gossner 1994: 52)
c. siba fi ili-da dolö boboga hü-fi fi-i=wabu before clan 3PL-DEF male fat mean-clan sit-PST=REP 'The old clan were a bunch of big fat people.' (Gossner 1994: 53)

Gossner describes a further verbal category, "aspect", that may prove upon further research to be a part of the evidential system in Edolo. The "aspect" markers $-s a$ and -sebe are primarily used in describing present-time events, and apparently have a "conjunct-disjunct"-like distribution pattern, with -sa occurring with 1 st person subjects in statements and 2nd person subjects in questions, and -sebe occurring elsewhere (Gossner 1994: 47). This distinctive 
pattern, discussed further in Section 4.3, suggests that these markers are evidential, and that $-s a$ encodes participatory information source.

Like with Bogaia and Fasu, there is no evidence in the available data that the Edolo sensory evidential is specifically restricted to auditory evidence, and we have assumed that it can be used for non-visual sensory evidence more generally. The narrower auditory distinction would be typologically unusual (Aikhenvald 2004: 63-65, 167-170; Anderson 1986: 279), and it remains important to establish whether any of these three languages do, indeed, have a specific "hearing" evidential that is never used for other senses (for example, as analysed for Kashaya, see Oswalt 1986: 37-38).

3.8.4. Onabasulu. Information concerning Onabasulu was provided by Anne Dondorp (personal communication, July 2009). The only narrow evidential marker so far identified in the language is a "direct witness" marker, $=s o$ (presumably cognate with Edolo - sio $)$ which is applied following the general past inflection, $-l u$. We do not know if the direct witnessing is restricted to visual evidence only, or can also describe other sensory evidence. In his discussion of empirical attitudes to evidence in Onabasulu culture, Ernst (1991: 203) mentions that the language has "a grammatical structure which indicates whether something being reported has been seen by the speaker or whether his knowledge is second-hand", implying that there is a dedicated structure for marking indirect evidence in contrast to the direct witness marker.

Other bound morphemes in Onabasulu that are relevant to evidentiality are a quotative $-b i$, which may function to mark reported information source, and a morpheme -me, which specifies that the situation described represents new (and perhaps surprising) information for the addressee. The quotative $-b i$ and addressee-oriented mirative -me can co-occur with the evidential marker -so, showing they do not form a single paradigm. As our current knowledge of the Onabasulu evidential categories is very limited, we do not include them in further comparative tables in Section 4.

\subsection{The eastern edge: Melpa and Wiru}

Melpa varieties spoken to the east of the Angal group, and the isolate Wiru spoken to the east of Kewa, are not described as having systematic evidential morphology (Head 2010, Kerr 1967, Melliger 2005, Merlan \& Rumsey 1991, Stucky \& Stucky 1995) but do have some constructions that are relevant to information source marking and appear to reflect their contiguity with the evidentiality area.

Kerr (1967) makes a number of references to a possible evidential marker in Wiru. The verbal suffix - de precedes tense and subject inflections, and indicates that "the state or action expressed by the verb $[\ldots]$ cannot be or is not 
directly observed by either the speaker, the addressee, or both" (Kerr 1967: 102-103); cf. Tipton's description of the "lesser perception" suffix in Nembi (Section 3.5.7). The Wiru morpheme occurs with present or past tense suffixes, and typically only with 3rd person subjects. This marker would thus seem to represent an indirect evidential category (e.g., results/reported), as can be suggested for examples $(34 a, b)$ from Wiru.

a. $m e-a-m e-d e-k-o$

sit-SF-NEG-SF- ${ }^{?}$ RESU/REP-PST-he

'(We found out that) he was not at home.' (Kerr 1967: 103)

b. tone-na kai tine tu-a-de-k-o-lo anu

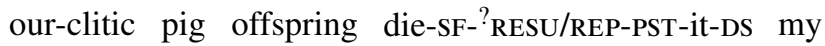

wene tubea keda to-k-o-lo

feelings big heavy do-PST-it-DS

$y a-k-u-y e$

wander-PST-I-DIRECT.SPEECH.PARTICLE

'Now that I have heard that our piglets have died I live (wander around) with a heavy heart.' (Kerr 1967: 34)

However, other examples provided by Kerr indicate that the meaning of - de is not that of a typical results or reported marker. The inclusion of Wiru as another language of the area with grammaticized information source marking is thus a significant issue for further investigation, but we exclude it from further comparative discussion in this article.

Finally, within the Melpa language varieties, Umbu-Ungu has two present tense inflections, "present action" and "present awareness", that distinguish what Head (2010: 111) describes as a "difference in perception". The present awareness tense "denotes an action of which the speaker has only just become aware" (Head 2010: 105), showing morphological representation of knowledge states, and specifically the time of perception, a widespread feature in the evidential systems of the region (Section 4.2). Furthermore, demonstratives in the Melpa languages, which can be used clause-finally to take semantic scope over an event or situation as well as over more typical NP referents (Strauss no date; June Head, personal communication; Alan Rumsey, personal communication), may cover some of the same territory as evidential markers (see also Kratochvíl 2011, Schapper \& San Roque 2011). Melpa demonstratives can indicate the nature of the speaker and addressee's epistemic or attentional access to a thing or event (San Roque et al. forthcoming, see also Hanks 2009), relating closely to evidential semantics, and to issues of shared knowledge that are relevant to several systems of the area (see Section 4.4). 


\section{Areal features}

In this section we summarize the evidential categories distinguished in each language (Section 4.1) and discuss typologically interesting features that are common to several languages of the group: distinctions of time and information source (Section 4.2); patterns concerning evidential marking and subject identity (Section 4.3); and further issues relating to the identity of the "perceiver" role (Section 4.4).

\subsection{The categories of evidential markers distinguished}

Table 15 shows the languages surveyed that have narrow evidential markers as verbal inflection and indicates the categories that are marked, as discussed in Sections 2.1 and 3.2.

The surveyed languages illustrate that, within the broader category of "direct" evidence, we cannot assume that participatory and visual semantics are always grouped together. Table 15 shows that there are at least three languages (Oksapmin, Foe, and Fasu) in the Highlands area for which a participatory category is distinguished from a visual(-sensory) category. Systems with opposed participatory(-factual) and visual(-sensory) evidential inflections challenge accepted typologies of evidentiality, which typically do not include participatory or factual categories, but treat participatory experience as something entirely separate from evidence (Willett 1988: 91), or as a secondary or extended meaning of visual, direct, and first-hand categories (Aikhenvald 2004: 186-193). Recognition of participatory information source as a potential crosslinguistically relevant evidential category is supported by the fact that for some languages it is sensible to understand visual semantics as a possible pragmatic ex-

Table 15. Evidentiality encoded by verbal inflection

\begin{tabular}{|c|c|c|c|c|c|c|}
\hline & \multirow{2}{*}{\multicolumn{3}{|c|}{ Direct }} & \multicolumn{3}{|c|}{ Indirect } \\
\hline & & & & \multicolumn{2}{|c|}{ Inferring } & \multirow[t]{2}{*}{ Reportec } \\
\hline & Participatory & Visual & Sensory & Results & Reasoning & \\
\hline Oksapmin & $\mathrm{x}$ & \multicolumn{2}{|c|}{$\mathrm{x}$} & & & \\
\hline Huli & & & $\bar{x}$ & & & \\
\hline Enga & & & $\mathrm{x}$ & & & \\
\hline Ipili & & & $\bar{x}$ & & & \\
\hline Angal & & $\mathrm{x}$ & \multicolumn{4}{|c|}{$\mathrm{x}$} \\
\hline$\overline{\text { Foe }}$ & $\bar{x}$ & $\mathrm{x}$ & $\mathrm{x}$ & $\mathrm{x}$ & $\mathrm{x}$ & \\
\hline \multirow[t]{2}{*}{ Fasu } & \multirow[t]{2}{*}{$\mathrm{x}$} & \multicolumn{2}{|c|}{$\mathrm{x}$} & & & \\
\hline & & $\mathrm{x}$ & & & & \\
\hline Edolo & & $\mathrm{x}$ & $\mathrm{x}$ & & & \\
\hline
\end{tabular}


Table 16. Evidentiality encoded by clitic or particle

\begin{tabular}{|c|c|c|c|c|c|c|}
\hline & \multirow{2}{*}{\multicolumn{3}{|c|}{ Direct }} & \multicolumn{3}{|c|}{ Indirect } \\
\hline & & & & \multicolumn{2}{|c|}{ Inferring } & \multirow[t]{2}{*}{ Reported } \\
\hline & Participatory & Visual & Sensory & Results & Reasoning & \\
\hline Oksapmin & & & & \multicolumn{2}{|c|}{$\mathrm{x}$} & $\mathrm{x}$ \\
\hline Duna & & $\bar{x}$ & $\bar{x}$ & $\bar{x}$ & $\mathrm{x}$ & $\bar{x}$ \\
\hline Bogaia & & $\bar{x}$ & $\bar{x}$ & & & \\
\hline Huli & & & & $\mathrm{x}$ & & \\
\hline Enga & & & & $\mathrm{x}$ & $\mathrm{x}$ & $\mathrm{x}$ \\
\hline Ipili & & & & $\mathrm{x}$ & & $\mathrm{x}$ \\
\hline Pole & & & & $\mathrm{x}$ & & \\
\hline Kewa & & $\mathrm{x}$ & & & & $\mathrm{x}$ \\
\hline$\overline{\text { Angal }}$ & & & & $\bar{x}$ & & \\
\hline Fasu & & & $\mathrm{x}$ & $\mathrm{x}$ & & $\mathrm{x}$ \\
\hline Kaluli & & & $\bar{x}$ & $\mathrm{x}$ & & \\
\hline$\overline{\text { Edolo }}$ & & & & & & $\bar{x}$ \\
\hline
\end{tabular}

tension of a participatory(-factual) evidential, rather than the other way around (see, e.g., McLendon 2003: 106-109).

Table 16 shows the languages surveyed which have non-inflectional narrow evidential markers, which are either phonologically bound morphemes or phonologically free particles.

As discussed in Section 2, a number of researchers have proposed hierarchies of strong to weak evidential categories, with indirect evidentials lower on the hierarchy than direct evidentials. The current data concerning the languages in this area, as shown in Tables 15 and 16, indicate that within the Highlands evidentiality area stronger evidence categories (e.g., visual) are generally more likely to be marked as verbal inflections, whereas weaker evidence categories (e.g., reported) are more likely to be non-inflectional (see also Kockelman 2004: 143 concerning predicted scope relations of direct versus indirect evidential expressions). For example, there is no language that includes both an inflectional results morpheme and a non-inflectional visual-sensory morpheme in its inventory. We can speculate that this reflects a higher frequency of direct category markers in speech, and is iconic of the greater "experiential distance" of events that are not directly known, with indirect evidentials being less integrated into the core verbal system.

The evidentials distinguished respect the contiguity of categories as predicted by a generalized hierarchy (i.e., there is no single evidential marker noted that "jumps" categories, e.g., marking both visual and reported information source, but not sensory information source). Kewa is unusual in apparently having a large "gap" between its marked categories. It is also noticeable that, 
for several of the languages, descriptions emphasise the incorporation of visual semantics into the results category, i.e., that the results of the event are typically visually observed (see, e.g., Duna, Huli, Pole, Kaluli). This concurs with de Haan's (2001) discussion of inference as a semantically complex evidential category that has affinities with direct as well as indirect evidence; the perceiver is not present at the event (a feature of reported information source), but still witnesses something (a feature of visual-sensory information source); see also Plungian's (2011) placement of inference within the crossover of "personal" and indirect evidence types, and van der Auwera \& Plungian's (1998: 85-86) treatment of inference as an "overlap category" between evidentiality and modality (a claim further examined, and ultimately rejected, by Boye 2010).

\subsection{Time reference and evidential markers}

The languages of the Highlands evidentiality area illustrate some of the more rare and complex relationships of time, event, and information source that are found in evidential systems. Most strikingly, Duna, Foe, Huli, Ipili, and Pole can mark a particular kind of "double tense" (Fleck 2003, 2007) within the results evidence category, indicating a time for the main predicate event and a time for the perception of evidence in a single clause. ${ }^{21}$

As discussed in Section 2.3, the perception event (experience of evidence) implied by an evidential marker can be understood as having its own temporal location, independent of the main predicate event. For participatory, visual, and sensory information sources, these two points in time (the perception event and the main predicate event), are typically simultaneous, as we participate in or witness things as they are happening. However, results evidence is more often perceived some time AFTER the main predicate event, creating two nonsimultaneous points in time that are of interest. In the languages in question, double tense is facilitated because the results evidential markers themselves encode time with respect to the speech event, distinguishing "current" and "previous" evidence. Thus, temporal features for the main predicate event and the perception event can be specified separately (see also Aikhenvald 2004: 101 concerning time reference in the Tariana reported category). ${ }^{22}$

21. Oksapmin may also distinguish the tense of the perception event and the main predicate event through the use of a complement clause construction; see Loughnane (2009) for details. This is beyond the scope of this article because it is a construction rather than a grammaticized evidential morpheme.

22. Note, however, that there are still several possible ways these time points can be triangulated. In Matses (and probably also in Duna), the main predicate event is located in time relative to the perception event (e.g., the event happened a long time before the results were observed) and the perception event is located relative to the speech event (e.g., the evidence was ob- 
In Huli and other Engan languages, the results evidential is added to a verb that is already inflected for tense. Examples $(17 \mathrm{a}, \mathrm{b})$ from Huli, reproduced here as $(35 \mathrm{a}, \mathrm{b})$, illustrate the contrast between current and previous results evidence for a past time event.

$$
\begin{array}{llll}
\text { a. } & \grave{i} & k \bar{a} g u a & \text { gìlibi-ru=da } \\
\text { [1sG } & \text { bad } & \text { write-1SG.PST=RESU.CURRENT }]
\end{array}
$$

'I wrote badly (going on the evidence of the bad writing on the paper before him).' (Rule 1974: 60)

b. i kāgua gīlibi-ru=ya

[1SG bad write-1SG.PST=RESU.PREVIOUS]

'I wrote badly (after having seen his bad writing in his book, and then going home without the book, and telling his parents).' (Rule 1974: 60)

Example (36) alternatively shows a construction that expresses inference concerning a future event. The verbal inflection - $l e$ 'FUT' indicates the tense of the main predicate event, and is followed by a current evidential: the speaker observes current evidence on a calendar concerning tomorrow's activities.

$$
\begin{aligned}
& \text { yawi ege Yulai ngabo lo-lebira-go, ina } \\
& \text { tomorrow month July? be-'FUT.3sG-BECAUSE 1PL } \\
& \text { hariga wago po-le=da } \\
& \text { track ? go-FUT=RESU.CURRENT } \\
& \text { 'Tomorrow will be the first of July, so we'll be going on a trek (said } \\
& \text { on looking at the calendar).' (Rule 1974: 61) }
\end{aligned}
$$

In Foe, time reference values for both time points are expressed in one inflection (see Footnote 13 concerning segmentation of these forms). In (37a), the speaker infers a present time event from current evidence. Example (37b) also expresses an inference from current evidence, but the main predicate event is specified as far past.

a. agu amena wa-boba'ae PN ?men come-PRS.RESU.CURRENT

'The Augu [? ${ }^{\text {sic }}$ ] men are coming (can see the smoke rising on the Agu track).' (Rule 1977: 74)

b. Faso amenara u-biba'ae PN ?people go-FP.RESU.CURRENT

'The Fasu men have gone (going on the evidence of the empty house).' (Rule 1977: 75)

served shortly before speaking). However, in Foe, Huli, and Pole it appears that both the main predicate event and the perception event are marked relative to the speech event. 
In Duna, evidential markers can occur without any TAM inflection present on the verb, in which case the evidential is responsible for indicating the time reference of the event. With visual and sensory markers, the main predicate event and perception event are normally understood to occur simultaneously, so that, for example, the current sensory marker supplies a reading of present tense (38a), and the previous sensory marker provides a reading of past tense (38b). This is similar to the Foe situation, where a single marker provides two time specifications.

$$
\begin{aligned}
& \text { rinini wa=yarua } \\
& \text { spirit come=SENS.CURRENT } \\
& \text { 'The spirit is coming }\{\text { I feel }\} . \\
& \text { b. rinini wa=yatia } \\
& \text { spirit come=SENS.PREVIOUS } \\
& \text { 'The spirit had come }\{\text { I felt }\} .
\end{aligned}
$$

However, like in the Engan family languages, it is also possible to inflect the Duna verb independently, creating the possibility for overt double tense marking. In (39), the speaker indicates that they are experiencing current sensory evidence of a completed event, as the (irregular) verb 'come' is marked as perfective.

$$
\begin{aligned}
& \text { rinini ho=yarua } \\
& \text { spirit come.PFV=SENS.CURRENT } \\
& \text { 'The spirit has come }\{\text { I feel }\} . '
\end{aligned}
$$

Examples such as (37a) and (39) show a mixing of the semantics of visualsensory and results categories. Double tense, in which the main predicate event and a (current) visual or other sensory perception event are overtly marked as NON-simultaneous, suggests a semantically inferential reading. A similar pattern is seen with the visual marker $=k i$ in Bogaia, as it occurs with past tense verb forms (see (14b)).

As can be seen throughout Section 3, many of the languages in the area include a "far past" tense distinction in their verbal inflections, stimulating enquiry into the relationship between temporal distance and evidence (typically, the further back in time an event is, the less likely it is to be personal experience), identified by Plungian (2011: 23) as a crucial area for further work in evidentiality. The time/evidence relationship is reflected in at least two ways in languages of the area: the semantics of far past and indirect information source can be intertwined in a single morpheme, as seen in Huli; or, the combination of far past tense with a participatory evidential can trigger a factual information source interpretation (see (7) from Oksapmin). 


\subsection{Person implicature of evidentials}

Evidentials in Oksapmin, Foe, ${ }^{23}$ and Fasu show a typologically interesting implicature of the person of the subject. This person implicature is due to the intersection of three attributes of these languages: (i) subject person is not marked on the verb; (ii) subject NPs are optional; and (iii) participatory versus visual (-sensory) evidentiality is marked by verbal inflection.

As in Kashaya (Oswalt 1986: 43), we suggest that the participatory category in Oksapmin, Foe, and Fasu is understood to be the strongest (i.e., most reliable) kind of evidence a perceiver (commonly the speaker in statements and the addressee in questions) has for an event, as per the evidentiality hierarchies discussed in Section 2.2. Furthermore, having the role of agentive subject in an event will usually entail having participatory evidence for it. Thus, when a verb is marked with visual(-sensory) evidence, the perceiver is assumed NOT to be the subject or they would have given the stronger participatory evidence available to them. The subject person implicature is summarized in Table $17 .^{24}$

Table 17. Subject person implicature of evidential affixes

\begin{tabular}{lll}
\hline Evidential category & Used in statements & Used in questions \\
\hline Participatory & $\begin{array}{l}\text { Subject is speaker (i.e., 1st } \\
\text { person) }\end{array}$ & $\begin{array}{l}\text { Subject is addressee (i.e., 2nd } \\
\text { person) }\end{array}$ \\
Visual(-sensory) & $\begin{array}{l}\text { Subject is NOT speaker (i.e., } \\
\text { 2nd or 3rd person) }\end{array}$ & $\begin{array}{l}\text { Subject is NoT addressee (i.e., } \\
\text { 1st or 3rd person) }\end{array}$ \\
\hline
\end{tabular}

23. Rule (1977: 71) outlines this implicature quite explicitly as follows: "When my wife and I first analysed the Foe language, we had [participatory or factual] aspect classified as a 1st pers[on] subject-verb agreement, and the [seen] aspect [...] as a $2 \mathrm{nd} / 3 \mathrm{rd}$ pers[on] subjectverb agreement. It was not until later, when we came across numbers of examples of sentences wherein the [participatory or factual] aspect was used for actions which a 3rd person/s were doing, and also of the [seen] aspect being used for things the speaker was doing, that I realized that the basic relationship was not between subject $\&$ the verb, but between the speaker $\&$ the verb". His final remark comprises an early, independent identification of the deictic nature of evidential morphology.

24. Further data are needed to confirm whether the person implicature in Fasu extends to questions or is only present in statements. Note that in the case of Foe, there are distinct question inflection forms for each evidential category (Rule 1977: 86). The correlation of visual and sensory evidential marking with a non-speaker subject in statements and non-addressee subject in questions, as outlined in Table 17, also holds true for Duna and very possibly for other languages of the area with visual and sensory evidentials. Interestingly, Duna and Kaluli maintain a conjunct/disjunct-like person marking pattern in other verbal inflections that do not reference information source directly (San Roque 2008, Schieffelin 1985). Even Huli and Pole, with largely obligatory subject marking according to $1 \mathrm{st} / 2 \mathrm{nd} / 3 \mathrm{rd}$ person distinctions, show some features of conjunct/disjunct alignment in limited areas of the grammar (e.g., see Rule 1974: 24). 
The person implicature outlined in Table 17 is the same as that of "conjunct/disjunct" systems in other languages, where a particular verbal marking (the "conjunct") is associated with speaker subjects in statements and addressee subjects in questions, and contrastive, "disjunct" marking is associated with other environments. Conjunct/disjunct systems are sometimes described as a kind of person reference or agreement (see, e.g., Bickel \& Nichols 2007, Dixon 2010) but this is an uneasy fit, as the marking is not predictable according to our usual understanding of the grammatical category of person. Conjunct terms have also been described as evidential, or as having an evidential component, in several languages, for example Kathmandu Newari (Hargreaves 1991), Sherpa (Kelly 2004), Tibetan (Garrett 2001; Tournadre 1996; DeLancey 1985, 1986, 1990) and Akhvakh (Creissels 2008). DeLancey (2001: 372) argues the following:

[The conjunct/disjunct] distinction can be interpreted as part of the evidential system, where the conjunct forms represent the speaker's direct perception of the act of volition which leads to an action, and the disjunct form represents its absence [...]. Since only the perpetrator of an act can possibly have direct knowledge of the act of volition which led to it, this distinction can be made only in statements with first person actor and in questions with second person actor.

Aikhenvald (2004: 127) argues, however, that this is not the case:

Conjunct-disjunct person-marking systems are not evidential in nature [...]. They may however, be similar to evidentials in their semantic extensions, and also in their interaction with evidentials proper (if the language happens to have them).

One such similarity is the "non-volitionality" effect of non-canonical uses of visual-sensory and disjunct morphemes. In rare instances where 1st person occurs with a visual(-sensory) evidential, this can imply the subject's lack of volition or control (see, e.g., Rule 1977: 72, Curnow 2002b) and this effect has been widely discussed for disjunct terms in certain Tibeto-Burman languages (e.g., Hale 1980, Hargreaves 2005, Watters 2006).

The participatory and visual-sensory forms in Oksapmin, Fasu, and Foe are part of the grammaticized evidential systems of these languages. That these categories have exactly the same person implicature as conjunct/disjunct systems is unlikely due to chance. These languages highlight the relevance of participatory and visual-sensory evidentials to conjunct/disjunct systems, and suggest that in certain cases "conjunct" and "disjunct" terms can be analyzed as participatory and visual(-sensory) evidentials, respectively.

\subsection{Perspective and evidentiality}

As outlined in Sections 2.3 and 4.3, it is common for the perceiver projected by an evidential marker - the "evidential origo" who experiences the specified ev- 
idence - to be understood as the speaker. Typically, we talk about information sources from our own, individual, point of view, and many of the descriptions for the languages surveyed identify the speaker as the person who sees, hears, infers, etc. (see, for example, the original researchers' definitions of evidential markers shown in Tables 4, 5, 11, and 12).

The evidential markers of the surveyed area also illustrate several other possibilities with respect to the understanding of perceiver identity. Two of these, a "shift" to addressee perspective in questions, and to 3rd person perspectives in extended narrative (sometimes necessarily accompanied by reportative marking), are well attested throughout languages with evidential systems (albeit not always explicitly recognized as such, see Brugman \& Macaulay 2010). These phenomena of shift are illustrated in (40) for sensory category evidentials in Duna: (40a) reflects the evidential perspective of the current speaker, whereas in (40b) and (40c) the speaker projects the sensory experience of the addressee and of narrative-internal 3rd persons, respectively.

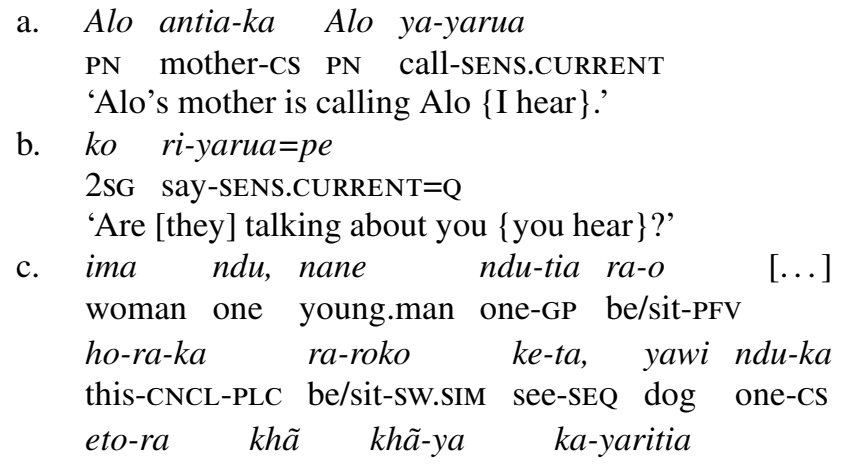

Further information concerning addressee perspective shifts and/or the expression of information source in narrative in Oksapmin, Duna, Ipili, Fasu, and Edolo can be found in the references already cited for those languages. Other kinds of perspective shift (e.g., in non-main clauses and in certain pragmatic contexts) are also possible for several of the surveyed languages (e.g., Oksapmin, Loughnane 2009; Duna, San Roque 2008; Foe, Rule 1977), and these remain important areas of enquiry for refining and expanding our understanding of the deictic nature of evidentiality (see, e.g., de Haan 2005, Hanks 2005, Jakobson 1957, Mushin 2001). 
Finally, the Highlands evidentiality area raises possibilities concerning the encoding of more than one (potential) perceiver of evidence. Languages such as Pole and the Angal varieties appear to formally indicate whether speaker and addressee share an evidential perspective for an event: for example did they witness it together, or did only one of them directly experience the event in question? ${ }^{25}$ This phenomenon has been previously described for Nambikuara/Mamaindê (Kroeker 2001: 62-65; but note the differing analysis of Eberhard 2009). Similar possibilities are described in Aymara and Jaqaru (Hardman 1986: 121-122), Southeastern Tepehuan (Willett 1991: 162-165), and Andoke (Landaburu 2007). This typologically unusual feature represents a multiple perspective construction concerning knowledge and/or attention of a proposition (Evans 2007; see also Bergqvist forthcoming). Duna also shows an unusual treatment of perceiver identity in its set of impersonal evidentials, by which a speaker indicates that an information source is available, without asserting who has experienced it. The systems of these languages thus reflect a concern not only with what an information source consists of, but also who has (or had) access to it. Such intersubjectively grounded phenomena suggest that even a narrow view of evidentiality may need to incorporate more explicit reference to the speech act situation into an adequate definition of evidence (cf. Mushin 2001).

\section{Concluding remarks}

In this article, we have presented material from a number of languages in the highlands of Papua New Guinea, confirming the existence of a significant evidentiality Sprachbund that includes at least six language families according to current classifications, and providing the first major investigation into the nature of the systems of this area. Overall, the evidential morphology of these languages is varied and complex, showing strong threads of commonality both within and beyond the area, and also intriguing distinctions and differences.

There is considerable scope - and need - for further descriptive work in the region, both in terms of contributing to our knowledge of under-described (and in some cases highly endangered) languages, and, more specifically, to typologies of evidentiality. A major point in this regard is the presence of a participatory evidential category in opposition to other evidential categories, including visual, in a number of the languages. These languages affirm that visual, participatory, and factual semantics need not be bundled together; that it is not always appropriate to identify visual evidentials as the "top" of a generalized eviden-

25. This feature is also relevant to the marking of results evidence as previous or current. We can expect that this distinction will correlate with symmetry of access to an information source, as current evidence is more likely to be immediately accessible to both speaker and addressee. 
tial hierarchy; and that participatory and factual information source types need to be explicitly incorporated into broader typological work (cf. Plungian 2011).

Other findings of particular interest are the hypothesis that "stronger" evidentials are more likely to be marked via verbal affixation and "weaker" evidentials by clitics or particles; the capacity to express "double tense" with evidential markers, among other time and information source relationships; interactions between person and evidentiality, in particular, the person implicature of participatory and visual(-sensory) evidentials; and insights into the deictic nature of evidentiality, and the potential for evidential systems to express shared as well as individual perspectives. The rich inventories of bound morphology present in the New Guinea evidentiality area encode culturally unique approaches to knowledge, and expand our understanding of how "access to mind", a central element of our capacity for social cognition, can be grammatically encoded in the world's languages.

Received: 4 September 2011 Revised: 22 November 2011
Max Planck Institute for Psycholinguistics Humboldt-Universität zu Berlin

Correspondence addresses: (San Roque) Max Planck Institute for Psycholinguistics, Postbus 310, 6500 AH Nijmegen, The Netherlands; e-mail: lila.sanroque@mpi.nl; (Loughnane) HumboldtUniversität zu Berlin, Institut für Asien- und Afrikawissenschaften, Seminar für Afrikawissenschaften, Unter den Linden, 10099 Berlin, Germany; e-mail: robyn.loughnane@staff.hu-berlin.de

Acknowledgements: Many individuals contributed to this survey through sharing previously unpublished descriptive material and sharing their expert knowledge of the languages. Special thanks to Hans Reithofer for sharing and discussing his Aklal Heneng data and providing us with a copy of Madden's pedagogical work, and to Dan Seeland, Terence Borchard \& Frances Ingemann, and Anne Dondorp for sharing and discussing their data and analyses of Bogaia, Ipili, and Onabasulu, respectively. It would not have been possible to include these languages in this survey without their generous assistance. Thanks also to Gabriel Lomas for additional discussion of the Huli material, to Bambi Schieffelin for her invaluable support in investigating Kaluli, and to June Head, Alan Rumsey, and Harald Hammarström for their assistance concerning the "eastern edge" languages, Umbu-Ungu, Ku Waru, and Wiru. Mark Donohue and Nicholas Evans gave very useful comments on an earlier version of this article, and Elisabeth Norcliffe provided helpful discussion in later stages. San Roque thanks the Rewapi and Rale communities (Kopiago SHP) and in particular Kenny Kendoli, Petros Kilapa, Kipu Piaro, and the late Richard Alo for provision and discussion of the Duna data. Loughnane thanks the Kusanap and Waulap communities and in particular Kila Dasyal, Julie James, Henna Kashat, Jack and Misseth Apipnok, and Reuben and Roselly Lapin. San Roque's field research was supported by an Australian Postgraduate Award, an Australian Research Council project grant ("Chanted tales from Highlands New Guinea"), and the Australian Research Council Discovery Project 0878126 "Language and social cognition: The design resources of grammatical diversity". Loughnane's field research was supported by an Australian Postgraduate Award and the Australian Research Council Discovery Project "Reciprocals across languages".

Abbreviations: 1/2/3 1st/2nd/3rd person; ANPH anaphoric; CNCL concealed/inner location; COMIT comitative; CONT continuous; CS contrasted subject; DEP dependent; DU dual; DAT dative; DEF definite; DEM demonstrative; DO direct object; DST distal (demonstrative); DS different subject; EMPH 
emphatic; ERG ergative; F feminine; FOC focus; FP far past; FUT future; GP group; HAB habitual; INDF indefinite; IPFV imperfective; IRR irrealis; M masculine; MID middle; NEG negative; NRP near past; o object; PCP participatory evidential; PFV perfective; PL plural; PLC place; PN proper name; POSS possessive; PQ polar question; PRS present; PRX proximal; PST past; Q interrogative particle; QUOT quotative; REAS reason evidential; RECG recognitional; REL relative; REP reported evidential; RESU results evidential; SENS non-visual sensory evidential; SEQ sequential; SF stem formative; SG singular; SIM simultaneous; ss same subject; sssIBS same sex siblings; sW switch; TODP today's past; TOP topic; TR transitive; vIS visual; YESTP yesterday's past. In Huli examples, underlining represents vocalic nasalization and diacritics indicate contrastive pitch.

\section{References}

Aikhenvald, Alexandra Y. 2004. Evidentiality. Oxford: Oxford University Press.

Aikhenvald, Alexandra Y. 2010. Imperatives and commands. Oxford: Oxford University Press.

Anderson, Lloyd B. 1986. Evidentials, paths of change, and mental maps: Typologically regular asymmetries. In Chafe \& Nichols (eds.) 1986, 273-312.

Barnes, Janet. 1984. Evidentials in the Tuyuca verb. International Journal of American Linguistics 50. 255-271.

Bergqvist, Henrik (forthcoming). The categorical expression of epistemic intersubjectivity in grammar: Towards a typology. In Proceedings of the Chronos 9 International Conference on Tense, Aspect, and Modality. Amsterdam: Rodopi.

Bickel, Balthasar \& Johanna Nichols. 2007. Inflectional morphology. In Timothy Shopen (ed.), Language typology and syntactic description (2nd edn.), Vol. 3: Grammatical categories and the lexicon, 169-240. Cambridge: Cambridge University Press.

Borchard, Terence \& Philip Gibbs. 2011. Parallelism and the poetics of tindi sung narratives from the Ipili region of Highland Papua New Guinea. In Rumsey \& Niles (eds.) 2011, 165-195.

Boye, Kasper. 2010. Semantic maps and the identification of cross-linguistic generic categories: Evidentiality and its relation to epistemic modality. Linguistic Discovery 8(1). 4-22. http:// journals.dartmouth.edu/cgi-bin/WebObjects/Journals.woa/2/xmlpage/1/article/344

Boye, Kasper \& Peter Harder. 2009. Evidentiality: Linguistic categories and grammaticalization. Functions of Language 16. 9-43.

Brugman, Claudia \& Monica Macaulay. 2010. Characterizing evidentiality. Manuscript, University of Wisconsin.

Bugenhagen, Robert D. 1995. A grammar of Mangap-Mbula: An Austronesian language of Papua New Guinea (Pacific Linguistics 101). Canberra: Australian National University.

Bybee, Joan. 1985. Morphology: A study of the relation between meaning and form. Amsterdam: Benjamins.

Chafe, Wallace L. 1986. Evidentiality in English conversation and academic writing. In Chafe \& Nichols (eds.) 1986, 261-272.

Chafe, Wallace L. \& Johanna Nichols (eds.). 1986. Evidentiality: The linguistic coding of epistemology, 273-312. Norwood, NJ: Ablex.

Chun, Soon Ae \& David A. Zubin. 1990. Experiential vs agentive constructions in Korean narrative. Berkeley Linguistics Society 16. 81-93.

Cochran, Anne. 1968. Notes on Yoliapi. Kivung 1(3). 134-145.

Cochrane, Nancy \& Dennis Cochrane. 1966. Duna essentials for translation. Manuscript submitted to the Grammar Department, Summer Institute of Linguistics, Papua New Guinea Branch.

Creissels, Denis. 2008. Person variations in Akhvakh verb morphology: Functional motivation and origin of an uncommon pattern. Sprachtypologie und Universalienforschung 61. 309-325.

Curnow, Timothy J. 2002a. Conjunct/disjunct marking in Awa Pit. Linguistics 40. 611-627.

Curnow, Timothy J. 2002b. Types of interaction between evidentials and first-person subjects. Anthropological Linguistics 44. 178-196.

Dahl, Östen. 1985. Tense and aspect systems. Oxford: Blackwell. 
de Haan, Ferdinand. 2001. The place of inference within the evidential system. International Journal of American Linguistics 67. 193-219.

de Haan, Ferdinand. 2005. Encoding speaker perspective: Evidentials. In Zygmunt Frajzyngier, Adam Hodges \& David Roods (eds.), Linguistic diversity and language theories, 379-397. Amsterdam: Benjamins.

de Haan, Ferdinand. 2008. Semantic distinctions of evidentiality. In Martin Haspelmath, Matthew Dryer, David Gil \& Bernard Comrie (eds.), The world atlas of language structures online. München: Max Planck Digital Library, chapter 77. http://wals.info/chapter/77

DeLancey, Scott. 1985. Lhasa Tibetan evidentials and the semantics of causation. Berkeley Linguistics Society 11. 65-72.

DeLancey, Scott. 1986. Evidentiality and volitionality in Tibetan. In Chafe \& Nichols (eds.) 1986, 203-213.

DeLancey, Scott. 1990. Ergativity and the cognitive model of event structure in Lhasa Tibetan. Cognitive Linguistics 1. 289-321.

DeLancey, Scott. 2001. The mirative and evidentiality. Journal of Pragmatics 33. 369-382.

de Vries, Lourens. 1990. Some remarks on direct quotation in Kombai. In Harm Pinkster \& Inge Genee (eds.), Unity in diversity: Papers presented to Simon C. Dik on his 50th birthday, 291-308. Dordrecht: Foris.

Dixon, Robert M. W. 2010. Basic linguistic theory, Vol. 2: Grammatical topics. Oxford: Oxford University Press.

Draper, Norman \& Sheila Draper. 2002. Dictionary of Kyaka Enga, Papua New Guinea (Pacific Linguistics 532). Canberra: Australian National University.

Eberhard, David. 2009. Mamaindê grammar: A Northern Nambikwara language in its cultural context (LOT Dissertation Series 236). Utrecht: LOT.

Ernst, Thomas M. 1991. Empirical attitudes among the Onabasulu. In Andrew Pawley (ed.), Man and a half: Essays in Pacific anthropology and ethnobiology in honour of Ralph Bulmer, 199-207. Auckland: The Polynesian Society.

Evans, Nicholas. 2007. View with a view: Towards a typology of multiple perspective. Berkeley Linguistics Society 31. 93-120.

Faller, Martina. 2002. Remarks on evidential hierarchies. In David Beaver, Luis D. Casillas Martínez, Brady Z. Clark \& Stefan Kaufmann (eds.), The construction of meaning, 89-111. Stanford, CA: CSLI.

Fedden, Olcher Sebastian. 2007. A grammar of Mian, a Papuan language of New Guinea. Melbourne: University of Melbourne doctoral dissertation. http://repository.unimelb.edu.au/ $10187 / 2044$

Fedden, Sebastian. 2011. A grammar of Mian. Berlin: De Gruyter Mouton.

Finegan, Edward. 1995. Subjectivity and subjectification: An introduction. In Dieter Stein \& Susan Wright (eds.), Subjectivity and subjectification: Linguistic perspectives, 1-15. Cambridge: Cambridge University Press.

Fleck, David. 2003. A grammar of Matses. Houston: Rice University doctoral dissertation.

Fleck, David. 2007. Evidentiality and double tense in Matses. Language 83. 589-614.

Foley, William A. 1986. The Papuan languages of New Guinea. Cambridge: Cambridge University Press.

Franklin, Karl J. 1964. Kewa verb morphology. In Alan Pence (ed.), Verb studies in five New Guinea languages, 100-130. Norman, OK: Summer Institute of Linguistics, University of Oklahoma.

Franklin, Karl J. 1971. A grammar of Kewa, New Guinea (Pacific Linguistics C-16). Canberra: Australian National University.

Franklin, Karl J. 2001. Kutubuan (Foe and Fasu) and Proto Engan. In Andrew Pawley, Malcolm Ross \& Darrell Tryon (eds.), The boy from Bundaberg: Studies in Melanesian linguistics in honour of Tom Dutton (Pacific Linguistics 514), 143-154. Canberra: Australian National University. 
Franklin, Karl J. \& Joice A. Franklin. 1978. A Kewa dictionary with supplementary grammatical and anthropological materials (Pacific Linguistics C-53). Canberra: Australian National University.

Garrett, Edward John. 2001. Evidentiality and assertion in Tibetan. Los Angeles: University of California at Los Angeles doctoral dissertation.

Giles, Glenda (no date). A guide to the pronunciation of Duna [and] Duna language lessons. Manuscript.

Gillespie, Kirsty \& Lila San Roque. 2011. Music and language in Duna pikono. In Rumsey \& Niles (eds.) 2011, 49-63.

Gordon, Raymond G. \& Barbara F. Grimes (eds.). 2005. Ethnologue: Languages of the world. 15th edn. Dallas: SIL International. http://www.ethnologue.com

Gossner, Jan D. 1994. Aspects of Edolo grammar. Arlington, TX: University of Texas at Arlington MA thesis.

Grice, Paul. 1975. Logic and conversation. In Peter Cole \& Jerry L. Morgan (eds.), Speech acts (Syntax and Semantics 3), 41-58. New York: Academic Press.

Grosh, Sylvia \& Andrew Grosh. 2004. Grammar essentials for the Kaluli language. Manuscript, Summer Institute of Linguistics, Papua New Guinea Branch. http://www.sil.org/pacific/png/ abstract.asp?id=51986

Guentchéva, Zlatka \& Jon Landaburu (eds.). 2007. L'énonciation médiatisée II: Le traitement épistémologique de l'information. Leuven: Peeters.

Güldemann, Tom. 2008. Quotative indexes in African languages: A synchronic and diachronic survey. Berlin: Mouton de Gruyter.

Hale, Austin. 1980. Person markers: Finite conjunct and disjunct verb forms in Newari. In Ronald L. Trail (ed.), Papers on South-East Asian linguistics no. 7 (Pacific Linguistics A-53), 95106. Canberra: Australian National University.

Haley, Nicole C. 2002. Ipakana yakaiya: Mapping landscapes, mapping lives: Contemporary land politics among the Duna. Canberra: Australian National University doctoral dissertation.

Hanks, William. 2005. Explorations in the deictic field. Current Anthropology 46. 191-220.

Hanks, William. 2009. Fieldwork on deixis. Journal of Pragmatics 41. 10-24.

Hardman, Martha James. 1986. Data-source marking in the Jaqi languages. In Chafe \& Nichols (eds.) 1986, 113-136.

Hargreaves, David. 1991. The conceptual structure of intentional action: Data from Kathmandu Newari. Berkeley Linguistics Society 17. 379-389.

Hargreaves, David. 2005. Agency and intentional action in Kathmandu Newar. Himalayan Linguistics 5. 1-48.

Head, June. 2010. Tense and mood pairs in Umbu-Ungu. In Joan Hooley (ed.), Papers on six languages of Papua New Guinea (Pacific Linguistics 616), 103-112. Canberra: Australian National University.

Healey, Alan. 1964. A survey of the Ok family of languages; Reconstructing proto-Ok. Canberra: Australian National University doctoral dissertation.

Healey, Phyllis M. 1965. Papers in New Guinea linguistics no. 3 (Pacific Linguistics A-5). Canberra: Australian National University.

Ingemann, Frances. 2011. The structure of chanted Ipili tindi. In Rumsey \& Niles (eds.) 2011, 197-206.

Jakobson, Roman. 1957. Shifters and verbal categories. Contribution to the Project "Description and Analysis of Contemporary Standard Russian", Department of Slavic Languages, Harvard University. Reprinted in Linda R. Waugh \& Monique Monville-Burston (eds.), On language, 386-392. Cambridge, MA: Harvard University Press, 1990.

Kelly, Barbara. 2004. A grammar of Sherpa. In Carol Genetti (ed.), Tibeto-Burman languages of Nepal: Manange and Sherpa (Pacific Linguistics 557), 232-440. Canberra: Australian National University. 
Kerr, Harland B. 1967. A preliminary statement of Witu grammar. Honolulu: University of Hawaii MA thesis.

Kini, Sisi. 2010. Toward a fluid definition of development projects: An ethnographic study of meanings ascribed by multiple stakeholders to a rural water supply and sanitation project, Southern Highlands, Papua New Guinea. Lincoln, New Zealand: Lincoln University MSSc dissertation.

Kockelman, Paul. 2004. Stance and subjectivity. Journal of Linguistic Anthropology 14. 127-150.

Kratochvíl, František. 2011. Discourse-structuring functions of Abui demonstratives. In Foong Ha Yap, Karen Grunow-Hårsta \& Janick Wrona (eds.), Nominalization in Asian languages: Diachronic and typological perspectives, 757-788. Amsterdam: Benjamins.

Kroeker, Menno. 2001. A descriptive grammar of Nambikuara. International Journal of American Linguistics 67. 1-87.

Landaburu, Jon. 2007. La modalisation du savoir en langue andoke (Amazonie colombienne). In Guentchéva \& Landaburu (eds.) 2007, 23-47.

Lang, Adrienne. 1973. Enga dictionary with English index (Pacific Linguistics C-20). Canberra: Australian National University.

Lawrence, Marshall. 1987. Viewpoint in Oksapmin. Language and Linguistics in Melanesia 16. 54-70.

Lawrence, Marshall. 1993. Oksapmin dictionary. Ukarumpa: Summer Institute of Linguistics. http://www.sil.org/pacific/png/abstract.asp?id=34252

Lawrence, Marshall. 2006. Oksapmin dictionary. 2nd edn. Ukarumpa: Summer Institute of Linguistics. http://www.sil.org/pacific/png/abstract.asp?id=49075

Lazard, Gilbert. 2001. On the grammaticalization of evidentiality. Journal of Pragmatics 33. 359367.

Lewis, M. Paul (ed.). 2009. Ethnologue: Languages of the world. 16th edn. Dallas: SIL International. http://www.ethnologue.com/

Loeweke, Eunice \& Jean May. 1980. General grammar of Fasu (Namo Me). In Don Hutchisson (ed.), Grammatical studies in Fasu and Mt. Koiali, 5-106. Ukarumpa: Summer Institute of Linguistics.

Logan, Tommy. 2008. Kasua grammar sketch. Manuscript, Summer Institute of Linguistics, Papua New Guinea Branch. http://www.sil.org/pacific/png/abstract.asp?id=50999

Lomas, Gabriel. 1988. The Huli language of Papua New Guinea. Sydney: Macquarie University doctoral dissertation.

Loughnane, Robyn. 2007. Expanding the typology of evidentiality: The participatory/factual in Oksapmin. Paper read at the Seventh Biennial Conference of the Association for Linguistic Typology, Paris.

Loughnane, Robyn. 2009. A grammar of Oksapmin. Melbourne: University of Melbourne doctoral dissertation. http://repository.unimelb.edu.au/10187/4788

Loughnane, Robyn \& Sebastian Fedden. 2011. Is Oksapmin Ok? - A study of the genetic relationship between Oksapmin and the Ok languages. Australian Journal of Linguistics 31. 1-42.

MacDonald, Lorna. 1990. Evidentiality in Tauya. Language and Linguistics in Melanesia 21. 3146.

Madden, B. (no date) [c.1960]. An introduction to Mendi grammar. Manuscript.

McLendon, Sally. 2003. Evidentials in Eastern Pomo with a comparative survey of the category in other Pomoan languages. In Alexandra Y. Aikhenvald \& R. M. W. Dixon (eds.), Studies in evidentiality, 101-129. Amsterdam: Benjamins.

Melliger, Markus. 2005. Phonology essentials: Pinai-Hagahai language. In Steve Parker (ed.), Phonological descriptions of PNG languages, 303-338. Ukarumpa: Summer Institute of Linguistics. http://www.sil.org/pacific/png/abstract.asp?id=48167

Merlan, Francesca \& Alan Rumsey. 1991. Ku Waru: Language and segmentary politics in the Western Nebilyer Valley, Papua New Guinea. Cambridge: Cambridge University Press. 
Mithun, Marianne. 1999. The languages of native North America. Cambridge: Cambridge University Press.

Mushin, Ilana. 2001. Evidentiality and epistemological stance: Narrative retelling. Amsterdam: Benjamins.

Oswalt, Robert L. 1986. The evidential system of Kashaya. In Chafe \& Nichols (eds.) 1986, 29-45.

Palmer, Frank R. 2001. Mood and modality. 2nd edn. Cambridge: Cambridge University Press.

Plungian, Vladimir. 2011. Types of verbal evidentiality marking: An overview. In Gabriele Diewald \& Elena Smirnova (eds.), Linguistic realization of evidentiality in European languages, 1558. Berlin: De Gruyter Mouton.

Quigley, Susan R. (forthcoming). The Awara verbal system (Pacific Linguistics). Canberra: Australian National University.

Reithofer, Hans. 2011. Skywalkers and cannibals: Chanted tales in the Angal (Mendi) language area. In Rumsey \& Niles (eds.) 2011, 207-245.

Ross, Malcolm. 2005. Pronouns as a preliminary diagnostic for grouping Papuan languages. In Andrew Pawley, Robert Attenborough, Jack Golson \& Robin Hide (eds.). Papuan pasts: Cultural, linguistic and biological histories of Papuan-speaking peoples (Pacific Linguistics 572), 15-65. Canberra: Australian National University.

Rule, William Murray. 1966. A grammatical description of the Duna (Yuna) language. Manuscript held at the Summer Institute of Linguistics, Papua New Guinea Branch, Ukarumpa.

Rule, William Murray. 1974. Statement of the phonology and grammar of the Huli language. Manuscript.

Rule, William Murray. 1977. A comparative study of the Foe, Huli and Pole languages of Papua New Guinea. Sydney: University of Sydney.

Rule, William Murray (no date). Statement of the alphabet and grammar of the Kaluli language. Manuscript.

Rumsey, Alan \& Don Niles (eds.). 2011. Sung tales from the Papua New Guinea Highlands: Studies in form, meaning and sociocultural context. Canberra: ANU E Press.

San Roque, Lila. 2006. Evidentiality in Duna. Handout from a seminar presented at the University of Sydney, 2 June.

San Roque, Lila. 2008. An introduction to Duna grammar. Canberra: Australian National University doctoral dissertation.

San Roque, Lila, Lauren Gawne, Darja Hoenigman, Julia Miller, Alan Rumsey, Stef Spronck, Alice Carroll \& Nicholas Evans (forthcoming). Getting the story straight: Language fieldwork using a narrative problem-solving task. Language Documentation \& Conservation.

Schapper, Antoinette \& Lila San Roque. 2011. Demonstratives and non-embedded nominalisations in three Papuan languages of the Timor-Alor-Pantar family. Studies in Language 35. 380-408.

Schieffelin, Bambi B. 1985. The acquisition of Kaluli. In Dan Slobin (ed.), The cross-linguistic study of language acquisition, 525-593. Hillsdale, NJ: Erlbaum.

Schieffelin, Bambi B. 1990. The give and take of everyday life: Language socialization of Kaluli children. Cambridge: Cambridge University Press.

Schieffelin, Bambi B. 1996. Creating evidence: Making sense of the written word in Bosavi. In Elinor Ochs, Emanuel Schegloff \& Sandra Thompson (eds.), Interaction and grammar, 435 460. Cambridge: Cambridge University Press.

Schieffelin, Bambi B. \& Steven Feld. 1998. Bosavi-English-Tok Pisin dictionary (Pacific Linguistics C-153). Canberra: Australian National University.

Seeland, Dan. 2007a. Bogaia grammar. Manuscript.

Seeland, Dan. 2007b. Bogaia verbal affixes. Manuscript.

Shaw, Karen. 1973. Grammatical notes on Samo. In Karl J. Franklin (ed.), The linguistic situation in the Gulf District and adjacent areas, Papua New Guinea (Pacific Linguistics C-26), 204 215. Canberra: Australian National University. 
Shaw, R. Daniel. 1973. A tentative classification of the languages of the Mt Bosavi region. In Karl J. Franklin (ed.), The linguistic situation in the Gulf District and adjacent areas, Papua New Guinea (Pacific Linguistics C-26), 189-203. Canberra: Australian National University.

Shaw, R. Daniel. 1986. The Bosavi language family. In Papers in New Guinea linguistics no. 24 (Pacific Linguistics A-70), 45-76. Canberra: Australian National University.

Siegl, Florian. 2004. Some comments on interaction between temporal and information deixis. Manuscript, Tartu Ülikool. http://lepo.it.da.ut.ee/ flos/Folder_PDF/Information\%20deixis. pdf

Sillitoe, Paul (no date). The knowing in indigenous knowledge: Alternative ways to view development, largely from a New Guinea Highlands' perspective. Manuscript.

Speas, Margaret. 2004. Evidentiality, logophoricity and the syntactic representation of pragmatic features. Lingua 114. 255-276.

Stewart, Jean. 1989. Aekyom language: Morphophonemic, phonetic and grammar statements. Manuscript.

Strauss, Hermann (no date). [Description of the Melpa language]. Manuscript.

Stucky, Alfred \& Dellene Stucky. 1995. Melpa verbs and morphophonemics: An interim report. Manuscript. http://www.sil.org/pacific/png/abstract.asp?id=51989

Suter, Edgar. 1997. A comparative look at the dual and plural forms of verb inflections and pronouns in Northeast New Guinea Papuan languages. Language and Linguistics in Melanesia 28. 17-68.

Tatevosov, Sergei. 2007. Evidentiality and mirativity in the Mishar dialect of Tatar. In Guentchéva \& Landaburu (eds.) 2007, 407-433.

Tipton, Ruth A. 1982. Nembi procedural and narrative discourse (Pacific Linguistics B-82). Canberra: Australian National University.

Tournadre, Nicolas. 1996. Comparaison des systèmes médiatifs de quatre dialectes tibétains (Tibétain Central, Ladakhi, Dzongkha et Amdo). In Zlatka Guentchéva (ed.), L'énonciation médiatisée, 195-213. Leuven: Peeters.

van der Auwera, Johan \& Vladimir Plungian. 1998. Modality's semantic map. Linguistic Typology 2. 79-124.

Voorhoeve, C. L. 1975. Central and Western Trans-New Guinea phylum languages. In Stephen A. Wurm (ed.), New Guinea area languages and language study (Pacific Linguistics C-40), Vol. 1: Papuan languages and the New Guinea linguistic scene, 345-459. Canberra: Australian National University.

Watters, David E. 2006. The conjunct-disjunct distinction in Kaike. Nepalese Linguistics 22. 300319.

Weiner, James F. 2001. The Foi incorporated land group: Law and custom in group definition and collective action in the Kutubu oil project area, PNG (State Society and Governance in Melanesia Working Papers 01/2). Canberra: Australian National University. http://ips.cap. anu.edu.au/ssgm/papers/working_papers/workingpaperjamesweiner.pdf

Willett, Thomas. 1988. A cross-linguistic survey of the grammaticalization of evidentiality. Studies in Language 12. 51-97.

Willett, Thomas. 1991. A reference grammar of Southeastern Tepehuan. Dallas: Summer Institute of Linguistics and the University of Texas at Arlington.

Wurm, Stephen A. \& Shirō Hattori. 1981. Language atlas of the Pacific area (Pacific Linguistics C-66/67). Canberra: Australian Academy of the Humanities. 